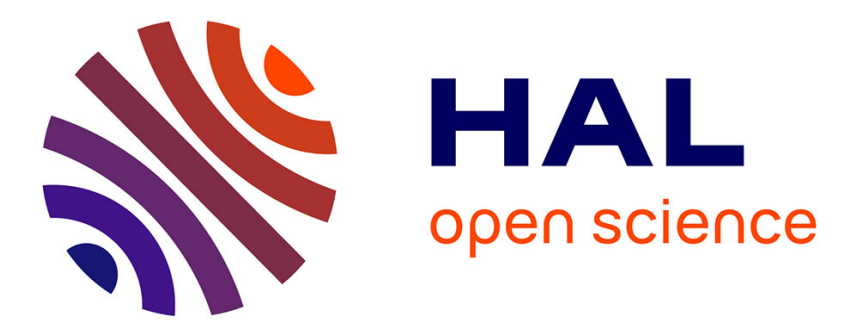

\title{
Bank equity Involvement in Industrial Firms and Bank Risk
}

\author{
Laetitia Lepetit, Frank Strobel
}

\section{To cite this version:}

Laetitia Lepetit, Frank Strobel. Bank equity Involvement in Industrial Firms and Bank Risk. 2012. hal-00916709

\section{HAL Id: hal-00916709 \\ https://hal-unilim.archives-ouvertes.fr/hal-00916709}

Preprint submitted on 10 Dec 2013

HAL is a multi-disciplinary open access archive for the deposit and dissemination of scientific research documents, whether they are published or not. The documents may come from teaching and research institutions in France or abroad, or from public or private research centers.
L'archive ouverte pluridisciplinaire HAL, est destinée au dépôt et à la diffusion de documents scientifiques de niveau recherche, publiés ou non, émanant des établissements d'enseignement et de recherche français ou étrangers, des laboratoires publics ou privés. 


\title{
Bank equity involvement in industrial firms and bank risk
}

\author{
Laetitia Lepetit \\ LAPE \\ Université de Limoges \\ Limoges, France
}

\author{
Frank Strobel \\ Department of Economics \\ University of Birmingham \\ Birmingham, UK
}

July 18,2012

\begin{abstract}
The regulatory framework in Europe does not prevent banks from taking large or controlling equity stakes in non-financial firms, potentially contributing to higher levels of bank risk and financial instability. Using a panel of European commercial banks for the period 2004-2008, we find that higher levels of equity positions in industrial firms and higher proportions of industrial firms where the bank is the majority shareholder lead to higher bank activity and insolvency risk. At low levels of shareholder protection, these risk measures are reduced when equity investments are held for longer, an effect attenuated at higher levels of shareholder protection.
\end{abstract}

Keywords: equity investment, bank risk, shareholder protection JEL classification: G21 


\section{Introduction}

Bank ownership in industrial, i.e. non-financial, firms has for many years been a common practice in a wide range of countries. In Europe, such activities are governed by the Second Banking Directive, which came into force on January 1, 1993; it stipulates that banks' equity investments in a single non-financial firm may not exceed $15 \%$ of the bank's capital, and not be larger than $60 \%$ of its capital for all such equity investments in non-financial firms taken together. These regulatory restrictions, however, do not necessarily prevent banks that are well capitalized from holding large, or even controlling, stakes in non-financial firms' capital, ${ }^{1}$ thereby potentially contributing to higher levels of bank risk and thus financial instability. In the United States, on the other hand, the question of whether banks should be allowed to hold equity positions in non-financial firms is still actively discussed, as U.S. banks have historically been prohibited from investing in the stock of firms for their own account. Santos and Rumble (2006) stress that this has not prevented them from making these investments through their trust business and from voting the stock they hold in trust; however, as this puts only their clients' investments at risk, this has generally no consequences for the banks' risk position.

There is a substantial, mostly empirical, literature studying the consequences of bank equity investments for firms, which examines the impact of such equity investments on firms' agency costs of debt, their funding, their performance, and their ability to recover from financial distress. ${ }^{2}$ Some recent studies also investigate the loan pricing effect of banks' voting stakes in borrowing firms (Ferreira and Matos 2012, Santos and Wilson 2010). However, from a public policy point of view, the expected impact of bank equity investments on bank risk is also of obvious interest, given its overall importance for financial stability.

Whether or not bank equity investments tend to raise or lower bank risk has

\footnotetext{
${ }^{1}$ This has been observed more generally by La Porta et al. (1999) in their study of the ownership structure of firms.

${ }^{2}$ See Santos (1998) and Barucci and Mattesini (2008) for detailed surveys of this literature.
} 
been studied mostly from a theoretical perspective, and seems to be far from a clear cut issue in the literature. From a portfolio theoretic perspective, substituting debt for (riskier) equity should raise bank profits at the cost of making them riskier. In Park (2000), having larger equity investments might lead the bank to encourage firms to take on riskier projects, which might increase the riskiness of the bank's combined debt and equity position in the firm. However, as argued by Pozdena (1991) and Kim (1992), a debt-equity contract may encourage firms to implement less risky strategies than a pure debt contract, as it lowers the outstanding value of debt to be repaid. John et al. (1994) and Santos (1999) then show that for banks making equity investments in addition to traditional lending, these two opposing effects may actually result in banks' portfolio risk being overall lowered, or as shown by Lepetit (2003), even lead to a U-shaped relationship, i.e. one where risk decreases for low levels of equity investment but increases thereafter. Boyd et al. (1998) further argue that when state verification is costly, allowing banks to take equity positions in addition to lending to firms may reduce their incentives to control moral hazard; as they could share in the potential benefits of "misallocating" investment capital, banks might spend fewer resources on monitoring firms' projects, leading to increased bank risk.

Intriguingly, this theoretical literature is complemented by very little corresponding empirical work, apart from Lepetit (2003) who studies the relationship between banks' risk and their total equity investment using a panel of European, US and Japanese universal and investment banks for the period 1991-1998; she finds a U-shaped relationship, i.e. for low levels of overall exposure to equity investment activities risk decreases, but it increases thereafter.

Our paper aims to further the empirical investigation of these issues. To this end, we go beyond analyzing the relationship between banks' overall exposure to equity investment activities and bank risk by examining in much more detail the strength of banks' equity involvement in individual industrial firms, their level of control in these firms, the length of time these equity investments are held for, and the consequences for bank risk implied by these. We also investigate whether 
the degree of shareholder protection, i.e. the ability of shareholders to exercise control over self-interested managers, matters in this context. For this purpose, we constructed a novel database with detailed information on banks' individual equity investments on a per-firm level, that allows a more refined empirical examination of the predictions generated by the existing theoretical literature. Given the established regulatory framework in Europe that allows banks to take possibly large, or even controlling, equity positions in non-financial firms, we focus our investigation on a panel of European commercial banks for the period 2004-2008.

We find that having higher levels of equity positions in industrial firms leads to both higher activity and insolvency risk for commercial banks. Additionally, higher proportions of industrial firms in which a commercial bank is the majority shareholder also lead to increased activity and insolvency risk. Both these results are economically significant, unaffected by the degree of shareholder protection, and consistent with the theoretical work of Boyd et al. (1998) and Park (2000), which argued that banks with larger equity investments might have strong incentives to drive firms to take on riskier projects. For low levels of shareholder protection, we find that banks with higher proportions of longer-term equity investments in industrial firms have lower activity and insolvency risk. At higher levels of shareholder protection, however, the magnitude of risk reduction associated with longer holding times of such equity investments decreases; this is consistent with a scenario where shareholders that are better able to exert influence over managers become less passive over time, pushing managers to adopt higher risk strategies.

Taking into account different dimensions of bank's equity involvement in industrial firms, we thus find that the greater banks' potential to influence the behavior of firms they hold equity investments in, the more such equity investments lead to increased bank risk. Overall, our results demonstrate that the existing regulatory framework in Europe seems to do little to prevent banks from taking large or even controlling equity stakes in non-financial firms, and might thereby contribute to higher levels of bank risk and thus financial instability.

Section 2 describes our research questions, presents our data and variables, and 
derives some descriptive statistics; Section 3 contains our empirical specification and presents our results; Section 4 discusses robustness and further issues; and Section 5 concludes the paper.

\section{Bank equity involvement: issues and measurement}

\subsection{Research questions}

As discussed in the introduction, the current state of the theoretical literature is unable to provide clear cut predictions as to how bank equity involvement in industrial firms impacts on bank risk. Banks engaging in equity investments may face increased risk through the mechanisms outlined by Boyd et al. (1998) and Park (2000); John et al. (1994) and Santos (1999), on the other hand, describe alternative scenarios in which such bank equity involvement might actually lead to lower bank risk.

These mixed theoretical predictions on the relationship between bank equity involvement and their level of risk give rise to a number of interesting empirical research questions, particularly as the degree of equity involvement of banks in industrial firms can manifest itself along several dimensions. We firstly examine

Question 1 What impact does a bank's level of equity investment in industrial firms have on bank risk?

This question is suggested directly by the theoretical literature; it could be taken further by examining whether the fact that a bank has controlling levels of equity investments in industrial firms has a particular impact on bank risk. Banks might have the potential to directly impose their risk preferences on firms in this case, which, as Park (2000) argues, could lead to those firms adopting riskier projects, increasing the riskiness of the bank's investment in the firm. This implies

Question 2 What impact does the fact that a bank has controlling equity stakes in industrial firms have on bank risk? 
An additional dimension of banks' equity involvement in industrial firms that might influence bank risk is the time such equity investments are held for. The risk implications of long-term investments could be very different from those stemming from more "hit-and-run" investment strategies, as longer-term investors might be less focussed on short-term earnings growth, with its accompanying higher risk (Stein 1988, Jacobs 1991, Porter 1992). An alternative channel might be that longer-term investors might become less actively involved in the firm, thereby potentially allowing risk-averse managers, whose human capital is tied to the firm, to favor less risky strategies (Jensen and Meckling 1976). This suggests

Question 3 What impact does the time a bank holds equity investments in industrial firms for have on bank risk?

A further interesting refinement would be to look at whether different degrees of shareholder protection could influence the relationship between the three dimensions of bank equity involvement and bank risk examined so far. The seminal work of La Porta et al. (1997, 1998) stresses the importance of the degree of investor protection provided by different countries' legal environments, as shareholders in countries with higher levels of shareholder protection will be better able to exercise control over self-interested managers. This results in

Question 4 Does the degree of shareholder protection have an impact on the relationship between bank risk and bank equity involvement in industrial firms?

To examine these questions, we constructed a novel database using firm-level data on European commercial banks' equity investments in industrial firms and measures reflecting the different dimensions of bank equity involvement under consideration, as described in the following sections.

\subsection{Sample definition}

Our study focusses on European commercial banks, for which we extracted both (unconsolidated) bank financial statement and firm-level equity investment data 
from BvD BankScope, which provides detailed information on the latter only starting 2004. Our data set therefore covers the period 2004-2008, and includes the following European countries: Austria, Belgium, Denmark, Finland, France, Germany, Greece, Italy, Luxembourg, Netherlands, Norway, Portugal, Spain, Sweden, Switzerland, and United Kingdom. We construct our data set from individual cross-sections using annual releases of BankScope to capture the time-varying dimension of banks' equity investment. BankScope provides unconsolidated financial statement data for 1909 European commercial banks for at least some of the period considered; when requiring a minimum four observations ${ }^{3}$ for our bank balance sheet variables, this number drops to 478. After some data cleaning, we are left with a final sample of 444 commercial banks; Table 1 gives a breakdown of these by country. Table 2 presents some general descriptive statistics for both our data set and the corresponding full sample of banks available under BankScope. For the majority of countries in our sample, the data coverage as measured in percent of total assets lies above $60 \%$, with bank activity characteristics in our sample very close to those in the wider BankScope one.

[Insert Tables 1 and 2]

\subsection{Equity investment measures}

BankScope provides detailed information for each firm in which a bank has an equity stake, in particular the percentage of the firm's equity held by the bank. In line with the existing theoretical literature, we focus our study on equity investments of banks in industrial firms. To examine our Questions 1-4, we then construct three particular measures to characterize the relevant degrees of bank equity involvement.

Firstly, to address Question 1, we calculate the percentage of individual industrial firms' total equity held by a bank, on a per-firm basis. We then calculate the

\footnotetext{
${ }^{3}$ This enables us to properly calculate the moments required for our risk measures, but substantially reduces the number of usable observations.
} 
average of these across all the industrial firms a bank invests in (FIRM_EQ). We also capture the level of control a bank exerts in industrial firms in which it has an equity stake, in line with Question 2, by computing the proportion of firms in which the bank is the majority shareholder, i.e. holds more than $50 \%$ of the firm's equity (PROP_CONTR). We are further able to compute for how long a bank holds an equity position in a given firm, which allows us to address Question 3. For this, we compute the proportion of firms in which a bank consecutively holds equity investments for 1, 2, 3, 4 or 5 years, respectively (PROP_HT1..PROP_HT5). These measures could have a potential bias problem, however: a measured holding time of, say, one year for an equity investment in the year 2004, the beginning of our sample period, could actually relate to a longer-run investment that just ends in that year. To correct for this potential mismeasurement, we drop observations with a holding time of one or two years where an equity investment occurred in the year 2004 and then calculate the proportion of firms a bank holds equity positions in for either 3, 4 or 5 years (PROP_LHT); this allows us to differentiate between short and longer-term equity investment behavior. Finally, to examine Question 4, we interact our equity investment measures FIRM_EQ, PROP_CONTR and PROP_LHT with an index that captures the different degrees of shareholder protection in place across Europe (see Section 3.1).

Table 3 shows some descriptive statistics of these measures over the period 2004-2008. The commercial banks in our sample have on average an equity position in 47 industrial firms (with a maximum of 3497), hold on average more than $30 \%$ of the firms' equity, and are the majority shareholder in more than $27 \%$ of the firms in which they hold an equity position. The largest proportion of equity holdings has a holding time of only one year, with a decrease in the proportions held for longer periods. Interestingly, though, commercial banks hold more of firms' equity the longer the time of their involvement. While total equity investments (both financial and non-financial) amount to around 2\% of total assets (EXPOS1) for the banks in our sample, banks' total equity investments represent on average more than $27 \%$ of their equity (EXPOS2). 
[Insert Table 3]

\subsection{Bank risk measures}

We consider several commonly used measures of bank risk computed from accounting data. ${ }^{4}$ To reflect bank activity risk, we use the standard deviation of return on equity ( $S D \_R O E$ ) and return on assets ( $\left.S D \_R O A\right)$, respectively. To proxy bank insolvency risk, we use the logarithm of two Z-score measures, ${ }^{5}$ defined as $L O G \_Z=\ln \left((100+R O E) / S D \_R O E\right)$ and, more commonly, $L O G \_Z P=$ $\ln \left(\left(R O A+E Q \_T A\right) / S D \_R O A\right)$, where $R O E$ and $R O A$ are average return on equity and return on assets, and $E Q \_T A$ is the average equity to total assets ratio (all in percentages).

Table 4 presents descriptive statistics for our different bank risk measures. To have an initial look at whether a bank's taking of equity positions in industrial firms has an impact on its risk, we first split the sample between banks that engage in such equity investments and those that do not, and perform mean tests on our summary statistics. We observe that commercial banks without equity investments in industrial firms have a lower standard deviation of return on equity $S D \_R O E$, accompanied by lower insolvency risk, i.e. higher levels of both our Z-score measures $L O G \_Z$ and $L O G \_Z P$. We then further split the subsample of banks that have equity investments in industrial firms into those with above and below average levels of such equity investment FIRM_EQ. Again, commercial banks with relatively high levels of equity investments in industrial firms display a higher standard deviation of return on equity $S D \_R O E$, which is further accompanied by a higher implied probability of insolvency.

\section{[Insert Table 4]}

\footnotetext{
${ }^{4}$ Only 58 of the 444 commercial banks in our sample are listed on the stock market; relying on market based risk measures would thus severely reduce the sample.

${ }^{5}$ Both Z-score measures are based on the Bienaymé-Chebyshev inequality, as in Hannan and Hanweck (1988) and Boyd et al. (1993). As Z-scores are highly skewed, we use their natural logarithms as in Laeven and Levine (2009) and Houston et al. (2010).
} 


\section{Empirical analysis}

\subsection{Model specification}

The univariate analysis of the previous section already indicated that banks with relatively high levels of equity investments in industrial firms display both higher activity and insolvency risk. We now extend our analysis to a multivariate framework to properly examine the four questions regarding the relationship between bank equity involvement in industrial firms and bank risk introduced in Section 2.1 .

In Questions 1-3, we examine if the degree of bank equity involvement in industrial firms, through their level of equity investment, the control they exercise and/or the time they hold these equity positions for, has an impact on bank risk. As the first dimension is highly correlated with the remaining two (see Table A1 in the Appendix), we examine these separately in the following two specifications

$$
\begin{aligned}
& D E P \_V A R_{i}=\alpha_{0}+\alpha_{1} F I R M \_E Q_{i}+\alpha_{2} E X P O S 1_{i}+\alpha_{3} N L_{-} T A_{i} \\
& +\alpha_{4} N_{N O N I N T_{i}}+\alpha_{5} E Q \_T A_{i}+\alpha_{6} L O G \_T A_{i}+\alpha_{7} G R \_T A_{i} \\
& +\alpha_{8} S U P \_R E G_{i}+\alpha_{9} A C T \_R E S T_{i}+\alpha_{10} X_{i}+\epsilon_{i} \\
& D E P \_V A R_{i}=\beta_{0}+\beta_{1} P R O P \_C O N T R_{i}+\beta_{2} P R O P \_L H T_{i}+\beta_{3} E_{X X O S 1_{i}} \\
& +\beta_{4} N L \_T A_{i}+\beta_{5} \text { NONINT }_{i}+\beta_{6} E Q \_T A_{i}+\beta_{7} L O G_{-} T A_{i} \\
& +\beta_{8} G R \_T A_{i}+\beta_{9} S U P \_R E G_{i}+\beta_{10} A C T_{-} R E S T_{i}+\beta_{11} X_{i}+\epsilon_{i}
\end{aligned}
$$

Our dependent variables $D E P \_V A R$ are the activity risk measures $S D_{-} R O A$ and $S D \_R O E$ and the insolvency risk measures $L O G \_Z$ and $L O G \_Z P$, as defined in Section 2.4. The degree of equity involvement of banks is represented in Equation (1) by the mean of each bank's equity investments as a percentage of individual industrial firms' total equity, FIRM_EQ. In Equation (2), we consider the two other dimensions of banks' equity involvement: PROP_CONTR is the proportion of firms a bank holds equity investments in where it is the majority shareholder, 
and PROP_LHT is the proportion of firms a bank holds equity positions in for either 3,4 or 5 years.

In both specifications, we control for the degree of exposure of banks to equity investment activities by including the ratio of total equity investments to total assets EXPOS1. ${ }^{6}$ We also introduce a set of commonly used control variables (as in Lepetit et al. 2008), accounting for business differences with the average net loans to total assets ratio $N L_{-} T A$ and the average ratio of net non-interest income to total operating income NONINT, for leverage with the average equity to total assets ratio $E Q \_T A$, for size with the logarithm of average total assets $L O G_{-} T A$, and for acquisition effects with the average growth rate of total assets GR_TA. Due to their strong correlation, we orthogonalize NL_TA with respect to NONINT (see Table A1). We add the average profitability measures $X \in\{R O A, R O E\}$ to the activity risk equations. We also introduce two country-level indices for strength of supervisory regime (SUP_REG) and bank activity restrictions $\left(A C T \_R E S T\right){ }^{7}$ drawn from the World Bank's 2008 Bank Regulation and Supervision database, in line with Laeven and Levine (2009) and Shehzad et al. (2010).

Finally, in Question 4, we investigate whether differences in regulations regarding shareholder protection existing across Europe have an impact on the relationship between bank risk and bank equity involvement in industrial firms, as better protected shareholders will be more able to exercise control over self-interested managers. For this we use the revised anti-director rights index in Djankov et al. (2008), which ranges in principle from 0 to 6 and considers shareholders' voting powers, their ease of participation in corporate voting, and their legal protection

\footnotetext{
${ }^{6} \mathrm{BvD}$ BankScope only provides the value of total equity investments in all types of firms together (i.e. financial and non-financial), so we are unable to characterize banks' exposure to equity investment in industrial firms on their own. In principle, we could reconstruct this if we had total equity data for the firms banks invest in; however, BankScope does not provide this. Attempts to find this information elsewhere failed, as we do not have a BvD identifier for on average 15600 firms per year; this makes identification of these through other means impracticable: as they are not covered by any of the Bureau van Dijk (BvD) databases, they are presumably of rather small size.

${ }^{7}$ The latter variable in particular allows for the different national degrees of regulations governing bank equity investments in non-financial firms.
} 
against expropriation by managers. For our European sample we observe a large degree of heterogeneity in the level of shareholder protection, with the index having a mean of 3.5 and ranging from 2 to 5 (see Table A2 in the Appendix). In order to examine Question 4, we then augment Equations (1-2) with interaction terms between the shareholder protection index $\left(S_{-}{ }_{-} P R O C T\right)$, scaled to have a minimum of zero for ease of interpretation, and our measures of bank equity involvement (i.e. FIRM_EQ, PROP_CONTR and PROP_LHT), as follows

$$
\begin{aligned}
& D E P \_V A R_{i}=\alpha_{0}+\alpha_{1} F I R M_{-} E Q_{i}+\alpha_{2} F I R M_{-} E Q_{i} \cdot S H_{-} P R O C T_{i}+\alpha_{3} E X P O S 1_{i} \\
& +\alpha_{4} N L_{-} T A_{i}+\alpha_{5} N_{N O N I N T_{i}}+\alpha_{6} E Q \_T A_{i}+\alpha_{7} L O G_{-} T A_{i} \\
& +\alpha_{8} G R \_T A_{i}+\alpha_{9} S U P \_R E G_{i}+\alpha_{10} A C T_{-} R E S T_{i}+\alpha_{11} S H_{-} P R O C T_{i}+\alpha_{12} X_{i}+\epsilon_{i} \\
& D E P_{-} V A R_{i}=\beta_{0}+\beta_{1} P R O P_{-} C O N T R_{i}+\beta_{2} P R O P P_{-} C O N T R_{i} \cdot S H_{-} P R O C T_{i} \\
& +\beta_{3} P R O P \_L H T_{i}+\beta_{4} P R O P \_L H T_{i} \cdot S H_{-} P R O C T_{i}+\beta_{5} E X P O S I_{i} \\
& +\beta_{6} N L_{-} T A_{i}+\beta_{7} N O N I N T_{i}+\beta_{8} E Q_{-} T A_{i}+\beta_{9} L O G_{-} T A_{i} \\
& +\beta_{10} G R \_T A_{i}+\beta_{11} S U P \_R E G_{i}+\beta_{12} A C T \_R E S T_{i}+\beta_{13} S H_{-} P R O C T_{i}+\beta_{14} X_{i}+\epsilon_{i}
\end{aligned}
$$

\subsection{Results and discussion}

Our regression analysis is restricted to be cross-sectional due to the time-invariant nature of our holding time measures. We need to allow for the possibility that the relationship between bank equity involvement and bank risk under investigation might in fact be facing an endogeneity problem: it is conceivable that banks which generally pursue higher risk strategies might actually be predisposed to engage in such equity investment activities in industrial firms. To address this problem in an instrumental variables framework, we ultimately drew on set of instruments related to general business conditions, drawn from the World Bank's World Development Indicators, as it proved impossible to find valid bank level 
instruments. $^{8}$

Rather than follow a simple instrumental variables approach, we use the twostep efficient generalized method of moments (GMM) estimator, which gives estimates that are efficient for, and standard errors that are robust to, arbitrary heteroskedasticity. From our larger set of instrument candidates, we determine an appropriate subset of instruments for each of our Equations (1-4) and each of the four risk measures. We check that these instruments are relevant by testing for underidentification using the Kleibergen-Paap rk LM statistic, ${ }^{9}$ which is heteroskedasticity-robust. As we have a sufficient number of instruments, we can test their validity, in the sense that they are appropriately uncorrelated with the error term, by performing Hansen tests of overidentifying restrictions; ${ }^{10}$ Hansen's J-statistic is similarly heteroskedasticity-robust. We then lastly test whether our equity involvement measures are in fact endogenous using the corresponding $\mathrm{C}$ (or GMM distance) test. ${ }^{11}$ When we cannot reject the null of exogeneity of regressors, we estimate our equations using simple OLS instead, correcting for heteroskedasticity following White's methodology.

The estimation results regarding Question 1 using Equation (1) are then presented in Table 5, those for Questions 2 and 3 using Equation (2) in Table 6, and the ones for Question 4 using Equations (3-4) in Tables 7 and 8. We note that the validity of the instruments used in our IV regressions, as tested with Hansen's J-statistic, is generally not put in doubt, despite the fact that these are not strictly bank specific.

\footnotetext{
${ }^{8}$ Our set of instrument candidates consists of the following: business entry rate (new registrations as $\%$ of total), business extent of disclosure index, cost of business start-up procedures ( $\%$ of GNI per capita), ease of doing business index, employment in industry (\% of total employment), highest marginal corporate tax rate, highest marginal individual tax rate, market capitalization of listed companies (\% of GDP), patent applications (residents), research and development expenditure (\% of GDP), researchers in R\&D (per million people), rigidity of employment index, start-up procedures to register a business (number), strength of legal rights index, time required to enforce a contract (days), time required to start a business (days), total tax rate (\% of profit).

${ }^{9}$ See Kleibergen and Paap (2006).

${ }^{10}$ See Hayashi (2000, pp. 217-218).

${ }^{11}$ See Hayashi (2000, pp. 218-220).
} 
Consistent with our univariate analysis of Section 2, we find in response to our Question 1 that higher equity involvement of commercial banks in industrial firms (FIRM_EQ) leads to higher levels of activity risk (Table 5). Additionally, commercial banks with higher levels of equity involvement present higher levels of insolvency risk. These results are consistent with the simple portfolio theoretic argument that increased equity holdings lead to increased risk, the channel outlined by Park (2000) that banks with larger equity investments might have more incentives to allow firms to pursue riskier projects, and the moral hazard related mechanisms described by Boyd et al. (1998) that might similarly result in increased bank risk. Furthermore, both of these results are economically significant: on average, a 1\% increase in a bank's mean level of equity investments (as a percentage of individual industrial firms' total equity) leads to an almost $3 \%$ increase in the bank's probability of insolvency, ${ }^{12}$ and a roughly half percent increase in its activity risk ( $\left.S D \_R O A, S D \_R O E\right)$.

Addressing Questions 2 and 3, using our alternative specification of Equation (2), we find that the two complementary dimensions of bank equity involvement in industrial firms matter. Commercial banks that have a higher proportion of investment in firms where they are the majority shareholder (as expressed by PROP_CONTR) have both higher activity and insolvency risk (Table 6). This is in support of the arguments of Park (2000) that banks have the incentive, and as majority shareholder the means, to drive firms to take on riskier projects. In terms of economic significance, we find that a $1 \%$ increase in the proportion of industrial firms where a bank is the majority shareholder leads on average to a roughly $2 \%$ increase in the bank's probability of insolvency, but only a one fifth percent increase in its activity risk. Our results further show that commercial banks with higher proportions of longer-term equity investments (as measured by PROP_LHT) have lower activity risk, whereas the impact on insolvency risk is only weakly significant. This would be consistent with banks pursuing "hit-and-

\footnotetext{
${ }^{12}$ Note that the Bienaymé-Chebyshev inequality implies an upper bound of the probability of insolvency $p$ as $p \leq[\exp (M)]^{-2}$ where $M \in\left\{L O G_{-} Z, L O G_{-} Z P\right\}$, as in Hannan and Hanweck (1988) and Boyd et al. (1993).
} 
run" strategies regarding firms with riskier projects, but adopting more long term investments in firms with less risky behavior, or the alternative mechanism where long-term investors become less actively involved in the firm, potentially allowing managers to favor less risky strategies. The impact of longer holding times is only economically significant for banks' insolvency risk: on average, a $1 \%$ increase in a bank's proportion of longer-term investments in industrial firms leads to a $1.5 \%$ increase in its probability of insolvency.

We find for all our specifications that banks' overall exposure to equity investment activities, as measured by the ratio of total equity investments (financial and non-financial) to total assets (EXPOS1), has no significant impact on either activity or insolvency risk. Re-running our Equations (1) and (2) without our refined equity involvement measures (FIRM_EQ, PROP_CONTR and PROP_LHT) does, however, show that banks with higher ratios of total equity investments to total assets display higher activity and insolvency risk (see Table A3 in the Appendix). Taken together, we obtain the interesting result that bank risk is affected by banks' different dimensions of equity involvement in industrial firms, but appears unrelated to their overall equity investment activity and thus, by deduction, their equity involvement in non-industrial, i.e. financial firms.

Turning to Question 4, we observe from Table 7 that the relationship between the level of bank equity investment in industrial firms (FIRM_EQ) and bank activity and insolvency risk, estimated with Equation (3), does not depend on the degree of shareholder protection (SH_PROCT). In Table 8, we then examine the relationship between our two alternative measures of bank equity involvement and bank risk, estimated using Equation (4). Apart from for the $L O G \_Z P$ insolvency risk measure, we find that the degree of shareholder protection does not affect the relationship between the proportion of firms a bank is majority shareholder of and bank risk; as majority shareholder, the bank already has the ability to control the firm's manager, so the level of general shareholder protection becomes less relevant in this case.

We do, however, find that the degree of shareholder protection does have a 
significant impact on the relationship between both activity and insolvency risk and the time a bank's equity investments in industrial firms are held for. At low levels of shareholder protection, holding such equity investments for longer results in lower bank activity and insolvency risk, consistent with shareholders that are unable to exert strong direct influence on managers becoming more passive, thus leaving those managers to pursue less risky strategies. At higher levels of shareholder protection, longer holding times of equity investments lead to smaller decreases in bank activity risk, to the point that the impact becomes insignificant where shareholder protection is at its maximum; this is consistent with shareholders that are better able to exert influence over managers becoming less passive over time, pushing managers to adopt higher risk strategies. We observe a related pattern for the insolvency risk measures: longer holding times reduce the magnitude of the reduction of insolvency risk at median shareholder protection levels; however, the impact of longer holdings times actually becomes reversed at maximum levels of shareholder protection, i.e. holding its equity investments in industrial firms for longer increases a bank's insolvency risk in this case.

Overall we find that higher levels of equity positions in industrial firms are associated with both higher activity and insolvency risk. Additionally, higher proportions of industrial firms in which a commercial bank is the majority shareholder also lead to higher activity and insolvency risk. Both of these relationships are economically significant; neither of them, however, is strongly affected by the degree of shareholder protection. Banks with higher proportions of longer-term equity investments in industrial firms have lower activity and insolvency risk at low levels of shareholder protection. With higher levels of shareholder protection, the magnitude of risk reduction implied by longer holding times of such equity investments decreases; at the maximum level of shareholder protection, this results in the marginal effect of longer holding times becoming insignificant for activity risk, whereas it actually leads to increased levels of insolvency risk. Our results therefore show, across different dimensions of bank's equity involvement in industrial firms, that the more the bank has the ability to influence the behavior of 
firms or their managers, the more such equity investments lead to increased bank risk.

[Insert Tables 5-8]

\section{Robustness and further issues}

We explore several variations of our previous analysis to further investigate our results. We re-run Equations (1-2) on a sample containing only banks that actually engage in equity investments in industrial firms (i.e. with positive FIRM_EQ). We have 353 such banks, with a mean FIRM_EQ of 38.5\%; we obtain results very similar to the ones for the larger sample, with additionally a strongly significant reduction in bank insolvency risk associated with longer-term equity investments (see Tables 9-10). We further note the absence of an endogeneity problem for this sample, indicating that whether or not a bank pursues equity investment activities in industrial firms depends on its risk profile, whereas the different degrees of equity involvement for those banks that engage in this kind of activity do not depend on bank risk.

We then examine whether the relationship between the level of equity investment of banks and their level of risk is non-linear, a possibility demonstrated theoretically by Lepetit (2003) which shows that bank risk might decrease for low levels of equity investment in an industrial firm but then increase beyond a given point. For this we add the demeaned square of FIRM_EQ to Equation (1), but do not find any support for such a U-shaped relationship for our sample (Table 11). ${ }^{13}$

We further examine a possible size effect in the relationship between equity involvement and bank risk by running Equations (1-2) separately on samples containing large and small banks, respectively (with a threshold of total assets of one billion euros; see Tables 12-15). We find for both large and small banks that

\footnotetext{
${ }^{13}$ Note that this U-shaped relationship might be difficult to detect in our sample as the equity investment measure FIRM_EQ is averaged across all industrial firms a particular bank holds equity investments in.
} 
higher levels of equity positions in industrial firms, or higher proportions of industrial firms in which the bank is the majority shareholder, are associated with higher activity and insolvency risk. Longer term equity involvement in industrial firms decrease both activity and insolvency risk for large banks only, with no such effect observed for small banks.

[Insert Tables 9-15]

\section{Conclusion}

We examined whether the equity investments of banks in industrial firms have an impact on bank activity and insolvency risk. This is of obvious interest from a public policy point of view, not least because the theoretical literature's predictions of this relationship are far from clear cut. We constructed a novel database on European commercial banks for the period 2004-2008 which is fine enough to consider three dimensions of the characteristics of banks' equity involvement in individual industrial firms. We also examined whether the degree of shareholder protection, i.e. the ability of shareholders to exercise control over self-interested managers, matters in this context.

We found that commercial banks' having higher levels of equity positions in industrial firms results in both higher activity and insolvency risk. Additionally, higher levels of control in industrial firms, i.e. higher proportions in which a commercial bank is the majority shareholder, are also associated with higher activity and insolvency risk. Both of these results are economically significant: e.g., a 1\% increase in a bank's mean level of equity investments (as a percentage of individual industrial firms' total equity) leads on average to an almost $3 \%$ increase in the bank's probability of insolvency. These results are consistent with the theoretical work of Boyd et al. (1998) and Park (2000), which argued that banks with larger equity investments might have strong incentives to push firms to take on riskier projects; neither of these two relationships was found to be strongly affected by the degree of shareholder protection. 
When levels of shareholder protection are low, we found that banks with higher proportions of longer-term equity investments in industrial firms have lower activity and insolvency risk. At higher levels of shareholder protection, the magnitude of risk reduction associated with longer holding times of such equity investments decreases; when shareholder protection is at its maximum, the marginal effect of longer holding times becomes insignificant for activity risk as a consequence, whereas insolvency risk, on the other hand, actually increases when banks hold their equity investments for longer. This relationship is consistent with a scenario where shareholders that are better able to exert influence over managers become less passive over time, pushing managers to adopt higher risk strategies.

Considering different dimensions of bank's equity involvement in industrial firms, we thus observe that the greater banks' potential to influence the behavior of firms they hold equity investments in, the more such equity investments lead to increased bank risk. We importantly also find that the existing regulatory framework in Europe, which limits bank equity investments in terms of banks' level of capital, seems to do little to prevent banks from taking large or even controlling equity stakes in non-financial firms, thereby contributing to higher levels of bank risk and thus financial instability. Future regulatory reforms in this area, be it in Europe, the U.S. or elsewhere, might therefore consider limiting bank equity investments in terms of the individual firms' level of capital. However, the possibility of engaging in cross holdings might render such restrictions meaningless without further regulatory measures, which might explain the predominant current state of regulations in this area of bank activities.

\section{References}

Barucci, E., Mattesini, F., 2008. Bank shareholding and lending: complementarity or substitution? Some evidence from a panel of large Italian firms. Journal of Banking \& Finance 32, 2237 - 2247. 
Boyd, J.H., Chang, C., Smith, B.D., 1998. Moral hazard under commercial and universal banking. Journal of Money, Credit \& Banking 30, 426-468.

Boyd, J.H., Graham, S.L., Hewitt, R.S., 1993. Bank holding company mergers with nonbank financial firms: effects on the risk of failure. Journal of Banking \& Finance 17, 43-63.

Djankov, S., La Porta, R., Lopez-de-Silanes, F., Shleifer, A., 2008. The law and economics of self-dealing. Journal of Financial Economics 88, 430 - 465.

Ferreira, M.A., Matos, P., 2012. Universal banks and corporate control: evidence from the global syndicated loan market. Review of Financial Studies (forthcoming).

Hannan, T.H., Hanweck, G.A., 1988. Bank insolvency risk and the market for large certificates of deposit. Journal of Money, Credit \& Banking 20, 203-211.

Hayashi, F., 2000. Econometrics. Princeton University Press, Princeton, N.J.

Jacobs, M.T., 1991. Short-term America. Harvard Business School Press, Boston, MA.

Jensen, M.C., Meckling, W.H., 1976. Theory of the firm: managerial behavior, agency costs and ownership structure. Journal of Financial Economics 3, 305360.

John, K., John, T.A., Saunders, A., 1994. Universal banking and firm risk-taking. Journal of Banking \& Finance 18, 307-323.

Kim, S.B., 1992. Corporate financing through a shareholder bank: lessons from Japan. Pacific Basin Working Paper Series - Federal Reserve Bank of San Francisco 92-03.

Kleibergen, F., Paap, R., 2006. Generalized reduced rank tests using the singular value decomposition. Journal of Econometrics 133, 97 - 126. 
La Porta, R., Lopez-de Silanes, F., Shleifer, A., Vishny, R.W., 1997. Legal determinants of external finance. Journal of Finance 52, 1131-1150.

La Porta, R., Lopez-de Silanes, F., Shleifer, A., Vishny, R.W., 1998. Law and finance. Journal of Political Economy 106, 1113-1155.

La Porta, R., Lopez-de Silanes, F., Shleifer, A., Vishny, R.W., 1999. Corporate ownership around the world. Journal of Finance 54, 471-517.

Laeven, L., Levine, R., 2009. Bank governance, regulation and risk taking. Journal of Financial Economics 93, 259 - 275.

Lepetit, L., 2003. Banques universelles et participations des banques dans le capital des entreprises. Revue économique 54, 857-885.

Lepetit, L., Nys, E., Rous, P., Tarazi, A., 2008. Bank income structure and risk: an empirical analysis of European banks. Journal of Banking \& Finance 32, 1452-1467.

Park, S., 2000. Effects of the affiliation of banking and commerce on the firm's investment and the bank's risk. Journal of Banking \& Finance 24, 1629-1650.

Porter, M.E., 1992. Capital choices: changing the way America invests in industry. Journal of Applied Corporate Finance 5, 4-16.

Pozdena, R.J., 1991. Why banks need commerce powers. Economic Review Federal Reserve Bank of San Francisco 4, 18-30.

Santos, J.A.C., 1998. Banking and commerce: how does the United States compare to other countries? Economic Review - Federal Reserve Bank of Cleveland 34, 14-26.

Santos, J.A.C., 1999. Bank capital and equity investment regulations. Journal of Banking \& Finance 23, 1095-1120. 
Santos, J.A.C., Rumble, A.S., 2006. The American keiretsu and universal banks: investing, voting and sitting on nonfinancials' corporate boards. Journal of Financial Economics 80, 419 - 454.

Santos, J.A.C., Wilson, K.E., 2010. Does banks' corporate control benefit firms? Evidence from US banks' control over firms' voting rights. Mimeo.

Shehzad, C.T., de Haan, J., Scholtens, B., 2010. The impact of bank ownership concentration on impaired loans and capital adequacy. Journal of Banking \& Finance 34, $399-408$.

Stein, J.C., 1988. Takeover threats and managerial myopia. The Journal of Political Economy 96, 61-80. 


\section{Table 1. Distribution of banks by country and type}

\begin{tabular}{|c|c|c|c|c|c|}
\hline \multirow[t]{2}{*}{ Country } & \multicolumn{3}{|c|}{ Our sample of commercial banks } & \multirow{2}{*}{$\begin{array}{c}\text { Total number of } \\
\text { commercial banks in } \\
\text { BankScope }\end{array}$} & \multirow[t]{2}{*}{ \% Total assets ${ }^{\mathrm{a}}$} \\
\hline & Large & Small & Total & & \\
\hline Austria & 8 & 15 & 23 & 91 & 41.30 \\
\hline Belgium & 9 & 3 & 12 & 60 & 37.28 \\
\hline Denmark & 15 & 16 & 31 & 72 & 59.59 \\
\hline Finland & 4 & 1 & 5 & 11 & 65.45 \\
\hline France & 46 & 24 & 70 & 262 & 57.12 \\
\hline Germany & 31 & 52 & 83 & 277 & 62.81 \\
\hline Greece & 7 & 0 & 7 & 27 & 66.23 \\
\hline Ireland & 0 & 0 & 0 & 43 & 0 \\
\hline Italy & 56 & 2 & 58 & 227 & 63.51 \\
\hline Luxembourg & 29 & 10 & 39 & 141 & 61.88 \\
\hline Netherlands & 1 & 0 & 1 & 56 & 0.18 \\
\hline Norway & 1 & 0 & 1 & 23 & 18.51 \\
\hline Portugal & 2 & 2 & 4 & 35 & 65.05 \\
\hline Spain & 19 & 3 & 22 & 115 & 76.28 \\
\hline Sweden & 4 & 5 & 9 & 25 & 85.45 \\
\hline Switzerland & 12 & 51 & 63 & 242 & 66.93 \\
\hline U.K. & 12 & 4 & 16 & 202 & 8.64 \\
\hline Total & 256 & 188 & 444 & 1909 & Median $=61.88$ \\
\hline
\end{tabular}

Large/small banks have total assets larger/smaller than 1 billion $€$.

a \% Total assets represents total assets of commercial banks we consider in our sample divided by total assets of commercial banks of the full sample of banks provided by BvD BankScope for the year 2008. 
Table 2. General descriptive statistics, on average over the period 2004-2008

\begin{tabular}{|c|c|c|c|c|c|c|c|c|c|}
\hline & DEP_TA & NL_TA & EQ_TA & LLP_TA & NONINT & ROA & ROE & GR_TA & TA \\
\hline \multicolumn{10}{|c|}{ Full sample of commercial banks available in BankScope (1909 banks) } \\
\hline Mean & 74.76 & 55.65 & 10.79 & 0.43 & 32.83 & 0.64 & 6.40 & 9.14 & 8033.26 \\
\hline Minimum & 0 & 0 & 0 & -24.43 & -279.65 & -49.82 & -148.10 & -99.65 & 0.50 \\
\hline Maximum & 99.23 & 99.95 & 100 & 29.13 & 290.48 & 48.67 & 136.01 & 285.03 & 2246380 \\
\hline Std. Dev. & 19.72 & 23.14 & 11.94 & 0.88 & 25.11 & 2.03 & 10.65 & 21.54 & 57787.71 \\
\hline \multicolumn{10}{|c|}{ Our sample of commercial banks (444 banks) } \\
\hline Mean & 73.01 & 52.15 & 9.43 & 0.39 & 42.92 & 0.87 & 9.93 & 12.01 & 25331.75 \\
\hline Minimum & 0.19 & 0.00 & 0.96 & -7.37 & -87.78 & -3.01 & -65.62 & -31.21 & 20.30 \\
\hline Maximum & 98 & 99.21 & 84.00 & 29.13 & 110.55 & 8.70 & 71.38 & 101.49 & 1476787 \\
\hline Std. Dev. & 19.03 & 28.67 & 7.63 & 1.06 & 25.38 & 1.12 & 10.67 & 14.10 & 112872.8 \\
\hline
\end{tabular}

Variable definitions (all variables are expressed in percentages, except $T A$ which is in millions of Euros): $D E P \_T A=$ deposits/total assets; $N L \_T A=$ net loans/total assets; $E Q \_T A=$ equity/total assets; $L L P \_T A=$ loan loss provisions/total assets; NONINT= net non interest income/net operating income; $R O A=$ return on assets; $R O E=$ return on equity; $G R \_T A=$ annual growth rate of total assets; $T A=$ total assets (millions Euros). 
Table 3. Descriptive statistics of bank equity investment measures, over the period 2004-2008

\begin{tabular}{|c|c|c|c|c|c|c|}
\hline & N_FIRMS & FIRM_EQ & PROP_CONTR & FIRM_EQ_CONTR & EXPOS1 & EXPOS2 \\
\hline Mean & 47.66 & 30.96 & 27.87 & 91.12 & 1.90 & 27.31 \\
\hline Maximum & 3497.4 & 100 & 100 & 100 & 29.83 & 386.91 \\
\hline Minimum & 0 & 0 & 0 & 50 & 0 & 0 \\
\hline Std. Dev. & 236.06 & 28.92 & 29.34 & 11.33 & 3.40 & 45.39 \\
\hline
\end{tabular}

\begin{tabular}{|l|ccccc|}
\hline & PROP_LHT & PROP_HT1 & PROP_HT2 & PROP_HT3 & PROP_HT4 \\
\hline Mean & 36.32 & 44.23 & 16.69 & 15.85 & 13.18 \\
Maximum & 100 & 100 & 0 & 000 & 100 \\
Minimum & 0 & 32.87 & 20.28 & 0 & 105 \\
Std. Dev. & 34.92 & 0 & 24.79 & 0 \\
\hline
\end{tabular}

\begin{tabular}{|l|ccccc|}
\hline & FIRM_EQ_HT1 & FIRM_EQ_HT2 & FIRM_EQ_HT3 & FIRM_EQ_HT4 \\
\hline Mean & 38.56 & 42.73 & 50.43 & 56.68 & 100 \\
Maximum & 100 & 100 & 100 & 0.01 & 1 \\
Minimum & 0.01 & 0.01 & 35.73 & 35.03 & 0.01 \\
Std. Dev. & 31.41 & 33.55 & 0.01 & 32.69 \\
\hline
\end{tabular}

Variable definitions: N_FIRMS = number of industrial firms in which bank holds equity investments over the period 2004-2008; FIRM_EQ = mean of bank equity investments as percentage of individual industrial firms' total equity; $P R O P \_C O N T R=$ proportion of industrial firms in which bank is the majority shareholder (more than 50\% of equity); FIRM_EQ_CONTR = mean of equity investments as percentage of industrial firms' total equity where the bank is the majority shareholder; EXPOS1 = ratio of total equity investments (in financial and non-financial firms) to total assets; EXPOS2 = ratio of total equity investments (in financial and non-financial firms) to bank equity; $P R O P \_H T 1$ = proportion of industrial firms in which bank holds equity investment for 1 year, and analogously, PROP_HT2-HT5 for holding time of 2 to 5 years; FIRM_EQ_HT1 = mean of equity investments as percentage of industrial firms' total equity where the bank holds equity investment for 1 year, and analogously, FIRM_EQ_HT2-HT5 for 2 to 5 years. 
Table 4. Descriptive statistics of risk measures by level of bank equity involvement in industrial firms, over the period 2004-2008

\begin{tabular}{|c|c|c|c|c|}
\hline & \multicolumn{2}{|c|}{ Activity risk } & \multicolumn{2}{|c|}{ Insolvency risk } \\
\hline & SD_ROA & SD_ROE & LOG_Z & LOG_ZP \\
\hline \multicolumn{5}{|c|}{ All Commercial banks (444 banks) } \\
\hline Mean & 0.44 & 5.37 & 3.55 & 3.53 \\
\hline Std. & 0.51 & 5.36 & 1.21 & 1.19 \\
\hline \multicolumn{5}{|c|}{ Equity investments vs no equity investments } \\
\hline \multicolumn{5}{|c|}{ with equity investments (353 banks) } \\
\hline Mean & 0.46 & 5.77 & 3.38 & 3.36 \\
\hline Std. & 0.02 & 0.28 & 0.05 & 0.05 \\
\hline \multicolumn{5}{|c|}{ without equity investments (91 banks) } \\
\hline Mean & 0.40 & 3.80 & 4.21 & 4.19 \\
\hline Std. & 0.06 & 0.54 & 0.15 & 0.15 \\
\hline T-stat of mean test & 0.93 & $3.16^{* * *}$ & $-6.05 * * *$ & $-6.22 * * *$ \\
\hline \multicolumn{5}{|c|}{$\begin{array}{l}\text { High vs low level of equity involvement for banks with equity investments } \\
\text { with above average level of equity investments (175 banks) }\end{array}$} \\
\hline Mean & 0.50 & 6.62 & 3.22 & 3.20 \\
\hline Std. & 0.03 & 5.87 & 0.07 & 0.07 \\
\hline \multicolumn{5}{|c|}{ with below average level of equity investments (178 banks) } \\
\hline Mean & 0.42 & 4.94 & 3.54 & 3.51 \\
\hline Std. & 0.03 & 0.34 & 0.07 & 0.07 \\
\hline$T$-stat of mean test & 1.51 & $2.99 * * *$ & $-2.90 * * *$ & $-2.89 * * *$ \\
\hline
\end{tabular}

T-statistics for null hypothesis of identical means; ${ }^{* * *},{ }^{* *}$ and ${ }^{*}$ indicate significance at the $1 \%, 5 \%$ and $10 \%$ levels, respectively, for a bilateral test.

Variable definitions: $S D \_R O A=$ standard deviation of $R O A$; $S D \_R O E=$ standard deviation of $R O E$; $L O G \_Z=\log \left((100+R O E) / S D \_R O E\right) ; L O G \_Z P=\log \left(\left(R O A+E Q \_T A\right) / S D \_R O A\right)$, with EQ_TA = average equity to total assets ratio (in \%), $R O A=$ average return on assets (in \%) and $R O E=$ average return on equity (in \%). 
Table 5. Equity involvement in industrial firms and commercial bank risk (Equation 1), cross-sectional over the period 2004-2008

\begin{tabular}{|c|c|c|c|c|}
\hline & \multicolumn{2}{|c|}{ Activity risk } & \multicolumn{2}{|c|}{ Insolvency risk } \\
\hline & SD_ROA & SD_ROE & LOG_Z & LOG_ZP \\
\hline FIRM_EQ & $\begin{array}{c}0.00848^{* * *} \\
(0.008)\end{array}$ & $\begin{array}{c}0.0927^{* * *} \\
(0.010)\end{array}$ & $\begin{array}{c}-0.0418^{* * *} \\
(0.000)\end{array}$ & $\begin{array}{c}-0.0452^{* * *} \\
(0.000)\end{array}$ \\
\hline EXPOS1 & $\begin{array}{c}0.00108 \\
(0.857)\end{array}$ & $\begin{array}{l}0.0150 \\
(0.815)\end{array}$ & $\begin{array}{c}-0.00554 \\
(0.814)\end{array}$ & $\begin{array}{c}0.00646 \\
(0.807)\end{array}$ \\
\hline NL_TA & $\begin{array}{c}-0.0314^{* *} \\
(0.047)\end{array}$ & $\begin{array}{l}-0.196 \\
(0.360)\end{array}$ & $\begin{array}{c}0.00958 \\
(0.862)\end{array}$ & $\begin{array}{l}0.0254 \\
(0.650)\end{array}$ \\
\hline NONINT & $\begin{array}{c}0.000300 \\
(0.820)\end{array}$ & $\begin{array}{c}0.0283^{*} \\
(0.058)\end{array}$ & $\begin{array}{c}-0.00994^{* * *} \\
(0.003)\end{array}$ & $\begin{array}{c}-0.00911^{* * *} \\
(0.009)\end{array}$ \\
\hline EQ_TA & $\begin{array}{c}0.0163^{* *} \\
(0.016)\end{array}$ & $\begin{array}{c}-0.0818^{* *} \\
(0.017)\end{array}$ & $\begin{array}{c}0.00678 \\
(0.556)\end{array}$ & $\begin{array}{c}0.00901 \\
(0.450)\end{array}$ \\
\hline LOG_TA & $\begin{array}{c}-0.0604^{* * * *} \\
(0.000)\end{array}$ & $\begin{array}{l}-0.135 \\
(0.541)\end{array}$ & $\begin{array}{l}0.0790 \\
(0.141)\end{array}$ & $\begin{array}{l}0.0908^{*} \\
(0.099)\end{array}$ \\
\hline GR_TA & $\begin{array}{c}0.00305 \\
(0.240)\end{array}$ & $\begin{array}{l}0.0121 \\
(0.660)\end{array}$ & $\begin{array}{c}-0.00898 \\
(0.104)\end{array}$ & $\begin{array}{c}-0.00915^{*} \\
(0.097)\end{array}$ \\
\hline ROA & $\begin{array}{l}0.115^{* *} \\
(0.016)\end{array}$ & $\begin{array}{l}- \\
-\end{array}$ & $\begin{array}{l}- \\
-\end{array}$ & $\begin{array}{l}- \\
-\end{array}$ \\
\hline ROE & $\begin{array}{l}- \\
-\end{array}$ & $\begin{array}{c}0.000699 \\
(0.988)\end{array}$ & $\begin{array}{l}- \\
-\end{array}$ & $\begin{array}{l}- \\
-\end{array}$ \\
\hline SUP_REG & $\begin{array}{c}-0.0273^{*} \\
(0.100)\end{array}$ & $\begin{array}{c}-0.381^{* *} \\
(0.015)\end{array}$ & $\begin{array}{c}0.246^{* * *} \\
(0.000)\end{array}$ & $\begin{array}{l}0.234^{* * * *} \\
(0.000)\end{array}$ \\
\hline ACT_REST & $\begin{array}{l}0.0188 \\
(0.347)\end{array}$ & $\begin{array}{c}-0.173 \\
(0.434)\end{array}$ & $\begin{array}{l}-0.0316 \\
(0.551)\end{array}$ & $\begin{array}{l}-0.0592 \\
(0.288)\end{array}$ \\
\hline Constant & $\begin{array}{c}0.329 \\
(0.199) \\
\end{array}$ & $\begin{array}{l}6.612^{* * *} \\
(0.009)\end{array}$ & $\begin{array}{l}3.463^{* * *} \\
(0.000)\end{array}$ & $\begin{array}{c}3.695^{* * *} \\
(0.000)\end{array}$ \\
\hline Final estimation method & IV-GMM & IV-GMM & IV-GMM & IV-GMM \\
\hline IV tests (P-values): & & & & \\
\hline Endogeneity: FIRM_EQ & 0.023 & 0.061 & 0.000 & 0.000 \\
\hline EXPOS1 & 0.733 & 0.152 & 0.643 & 0.665 \\
\hline Underidentification & 0.000 & 0.000 & 0.001 & 0.001 \\
\hline Overidentifying restrictions & 0.486 & 0.125 & 0.117 & 0.163 \\
\hline Observations & 444 & 444 & 444 & 444 \\
\hline
\end{tabular}

P-values of coefficient estimates in parentheses, with $p<0.1^{*}, p<0.05^{* *}, p<0.01^{* * *}$.

Dependent variable definitions: $S D \_R O A=$ standard deviation of $R O A$; $S D \_R O E=$ standard deviation of ROE; $L O G \_Z=\log \left((100+R O E) / S D \_R O E\right) ; L O G \_Z P=\log \left(\left(R O A+E Q \_T A\right) / S D \_R O A\right)$, with $E Q \_T A=$ average equity to total assets ratio (in \%), $R O A=$ average return on assets (in \%) and $R O E=$ average return on equity (in \%). Independent variable definitions (on average over the period, except the regulatory indices): FIRM_EQ = mean of equity investments as percentage of individual industrial firms' total equity; EXPOS1 = ratio of total equity investments (in financial and non-financial firms) to total assets; $N L \_T A=$ net loans/total assets; NONINT = net non interest income/net operating income; $E Q \_T A=$ equity/total assets; $L O G \_T A=\log$ of total assets; $G R \_T A=$ annual growth rate of total assets; $S U P \_R E G=$ index for strength of supervisory regime; $A C T \_R E S T=$ index for bank activity restrictions.

IV tests: endogeneity tested with $\mathrm{C}$ test (H0: exogeneity); underidentification tested using the Kleibergen-Paap rk LM statistic (H0: irrelevant instruments); overidentifying restrictions tested using Hansen test (H0: valid instruments). 
Table 6. Equity involvement in industrial firms and commercial bank risk (Equation 2), cross-sectional over the period 2004-2008

\begin{tabular}{|c|c|c|c|c|}
\hline & \multicolumn{2}{|c|}{ Activity risk } & \multicolumn{2}{|c|}{ Insolvency risk } \\
\hline & SD_ROA & SD_ROE & LOG_Z & LOG_ZP \\
\hline PROP_CONTR & $\begin{array}{c}0.00245^{* * *} \\
(0.003)\end{array}$ & $\begin{array}{c}0.0395^{* * *} \\
(0.000)\end{array}$ & $\begin{array}{c}-0.0275^{* * *} \\
(0.009)\end{array}$ & $\begin{array}{c}-0.0327^{* * *} \\
(0.002)\end{array}$ \\
\hline PROP_LHT & $\begin{array}{c}-0.00122^{* *} \\
(0.045)\end{array}$ & $\begin{array}{c}-0.0117^{*} \\
(0.082)\end{array}$ & $\begin{array}{c}-0.0187^{*} \\
(0.053)\end{array}$ & $\begin{array}{c}-0.0144 \\
(0.132)\end{array}$ \\
\hline EXPOS1 & $\begin{array}{c}0.00387 \\
(0.657)\end{array}$ & $\begin{array}{l}0.0697 \\
(0.392)\end{array}$ & $\begin{array}{l}-0.0144 \\
(0.639)\end{array}$ & $\begin{array}{c}0.00868 \\
(0.765)\end{array}$ \\
\hline NL_TA & $\begin{array}{c}-0.0101 \\
(0.649)\end{array}$ & $\begin{array}{l}0.0107 \\
(0.960)\end{array}$ & $\begin{array}{c}0.0940 \\
(0.171)\end{array}$ & $\begin{array}{c}0.105 \\
(0.127)\end{array}$ \\
\hline NONINT & $\begin{array}{c}0.000924 \\
(0.524)\end{array}$ & $\begin{array}{c}0.0382^{* *} \\
(0.020)\end{array}$ & $\begin{array}{c}-0.0117^{* * *} \\
(0.003)\end{array}$ & $\begin{array}{c}-0.0103^{* * *} \\
(0.008)\end{array}$ \\
\hline EQ_TA & $\begin{array}{c}0.0245^{* * *} \\
(0.008)\end{array}$ & $\begin{array}{c}-0.0981^{* *} \\
(0.047)\end{array}$ & $\begin{array}{l}0.0239 \\
(0.172)\end{array}$ & $\begin{array}{l}0.0221 \\
(0.216)\end{array}$ \\
\hline LOG_TA & $\begin{array}{l}-0.0157 \\
(0.314)\end{array}$ & $\begin{array}{c}0.101 \\
(0.568)\end{array}$ & $\begin{array}{l}-0.0258 \\
(0.579)\end{array}$ & $\begin{array}{l}-0.0160 \\
(0.731)\end{array}$ \\
\hline GR_TA & $\begin{array}{c}0.00368 \\
(0.320)\end{array}$ & $\begin{array}{l}0.0143 \\
(0.663)\end{array}$ & $\begin{array}{c}-0.0122^{*} \\
(0.074)\end{array}$ & $\begin{array}{c}-0.0122^{*} \\
(0.078)\end{array}$ \\
\hline ROA & $\begin{array}{l}0.128^{* *} \\
(0.011)\end{array}$ & $\begin{array}{l}- \\
-\end{array}$ & $\begin{array}{l}- \\
-\end{array}$ & $\begin{array}{l}- \\
-\end{array}$ \\
\hline ROE & $\begin{array}{l}- \\
-\end{array}$ & $\begin{array}{l}0.0185 \\
(0.741)\end{array}$ & $\begin{array}{l}- \\
-\end{array}$ & $\begin{array}{l}- \\
-\end{array}$ \\
\hline SUP_REG & $\begin{array}{c}-0.0293 \\
(0.158)\end{array}$ & $\begin{array}{c}-0.365^{* *} \\
(0.045)\end{array}$ & $\begin{array}{l}0.206^{* * *} \\
(0.000)\end{array}$ & $\begin{array}{c}0.207^{* * *} \\
(0.000)\end{array}$ \\
\hline ACT_REST & $\begin{array}{l}-0.0256 \\
(0.161)\end{array}$ & $\begin{array}{c}-0.446^{* *} \\
(0.010)\end{array}$ & $\begin{array}{l}-0.0270 \\
(0.652)\end{array}$ & $\begin{array}{l}-0.0527 \\
(0.386)\end{array}$ \\
\hline Constant & $\begin{array}{c}0.509^{*} \\
(0.072) \\
\end{array}$ & $\begin{array}{c}8.704^{* * *} \\
(0.002)\end{array}$ & $\begin{array}{c}4.720^{* * *} \\
(0.000) \\
\end{array}$ & $\begin{array}{c}4.759^{* * *} \\
(0.000) \\
\end{array}$ \\
\hline Final estimation method & OLS & OLS & IV-GMM & IV-GMM \\
\hline $\begin{array}{l}\text { IV tests (P-values): } \\
\text { Endogeneity : PROP_CONTR }\end{array}$ & 0.108 & 0.0708 & 0.001 & 0.000 \\
\hline PROP_LHT & 0.120 & 0.116 & 0.002 & 0.010 \\
\hline EXPOS1 & 0.789 & 0.870 & 0.881 & 0.691 \\
\hline Underidentification & - & - & 0.000 & 0.000 \\
\hline Overidentifying restrictions & - & - & 0.723 & 0.680 \\
\hline Observations & 389 & 389 & 389 & 389 \\
\hline
\end{tabular}

P-values of coefficient estimates in parentheses, with $p<0.1^{*}, p<0.05^{* *}, p<0.01^{* * *}$.

Variable definitions: as defined in Table 5 and PROP_CONTR = proportion of firms a bank holds equity investment in where it is the majority shareholder; PROP_LHT = proportion of firms a bank holds equity positions in for a duration of either 3 , 4 or 5 years.

IV tests: endogeneity tested with $\mathrm{C}$ test (H0: exogeneity); underidentification tested using the Kleibergen-Paap rk LM statistic (H0: irrelevant instruments); overidentifying restrictions tested using Hansen test (H0: valid instruments). 
Table 7. Equity involvement in industrial firms, shareholder protection and commercial bank risk (Equation 3), cross-sectional over the period 2004-2008

\begin{tabular}{|c|c|c|c|c|}
\hline & \multicolumn{2}{|c|}{ Activity risk } & \multicolumn{2}{|c|}{ Insolvency risk } \\
\hline & SD_ROA & SD_ROE & LOG_Z & LOG_ZP \\
\hline FIRM_EQ & $\begin{array}{c}0.00640^{* *} \\
(0.027)\end{array}$ & $\begin{array}{l}0.105^{* * *} \\
(0.002)\end{array}$ & $\begin{array}{c}-0.0440^{* * *} \\
(0.000)\end{array}$ & $\begin{array}{c}-0.0423^{* * *} \\
(0.000)\end{array}$ \\
\hline FIRM_EQ ×SH_PROCT & $\begin{array}{c}-0.0000593 \\
(0.941)\end{array}$ & $\begin{array}{c}-0.00662 \\
(0.518)\end{array}$ & $\begin{array}{c}-0.00160 \\
(0.546)\end{array}$ & $\begin{array}{c}-0.00263 \\
(0.317)\end{array}$ \\
\hline EXPOS1 & $\begin{array}{c}0.00415 \\
(0.475)\end{array}$ & $\begin{array}{l}0.0120 \\
(0.853)\end{array}$ & $\begin{array}{c}0.00962 \\
(0.714)\end{array}$ & $\begin{array}{c}-0.00153 \\
(0.949)\end{array}$ \\
\hline NL_TA & $\begin{array}{c}-0.0190 \\
(0.286)\end{array}$ & $\begin{array}{c}-0.173 \\
(0.433)\end{array}$ & $\begin{array}{l}0.0285 \\
(0.622)\end{array}$ & $\begin{array}{l}0.0159 \\
(0.786)\end{array}$ \\
\hline NONINT & $\begin{array}{c}0.000551 \\
(0.675)\end{array}$ & $\begin{array}{l}0.0272^{*} \\
(0.071)\end{array}$ & $\begin{array}{c}-0.008966^{* *} \\
(0.011)\end{array}$ & $\begin{array}{c}-0.00912^{* *} \\
(0.011)\end{array}$ \\
\hline EQ_TA & $\begin{array}{c}0.0177^{* * *} \\
(0.010)\end{array}$ & $\begin{array}{c}-0.0806^{* *} \\
(0.025)\end{array}$ & $\begin{array}{c}0.00724 \\
(0.553)\end{array}$ & $\begin{array}{c}0.00386 \\
(0.751)\end{array}$ \\
\hline LOG_TA & $\begin{array}{c}-0.0399^{* *} \\
(0.019)\end{array}$ & $\begin{array}{c}-0.168 \\
(0.438)\end{array}$ & $\begin{array}{l}0.0846 \\
(0.128)\end{array}$ & $\begin{array}{l}0.0892 \\
(0.115)\end{array}$ \\
\hline GR_TA & $\begin{array}{c}0.00289 \\
(0.313)\end{array}$ & $\begin{array}{l}0.0138 \\
(0.620)\end{array}$ & $\begin{array}{c}-0.00861 \\
(0.118)\end{array}$ & $\begin{array}{c}-0.00810 \\
(0.147)\end{array}$ \\
\hline ROA & $\begin{array}{l}0.123^{* *} \\
(0.011)\end{array}$ & $\begin{array}{l}- \\
-\end{array}$ & $\begin{array}{l}- \\
-\end{array}$ & $\begin{array}{l}- \\
-\end{array}$ \\
\hline ROE & $\begin{array}{l}- \\
-\end{array}$ & $\begin{array}{c}-0.00707 \\
(0.878)\end{array}$ & $\begin{array}{l}- \\
-\end{array}$ & $\begin{array}{l}- \\
-\end{array}$ \\
\hline SUP_REG & $\begin{array}{c}-0.0342^{* *} \\
(0.034)\end{array}$ & $\begin{array}{c}-0.338^{* *} \\
(0.038)\end{array}$ & $\begin{array}{l}0.239^{* * *} \\
(0.000)\end{array}$ & $\begin{array}{c}0.249^{* * *} \\
(0.000)\end{array}$ \\
\hline ACT_REST & $\begin{array}{c}-0.00627 \\
(0.761)\end{array}$ & $\begin{array}{l}-0.190 \\
(0.399)\end{array}$ & $\begin{array}{l}-0.0618 \\
(0.300)\end{array}$ & $\begin{array}{l}-0.0604 \\
(0.318)\end{array}$ \\
\hline Constant & $\begin{array}{c}0.470^{*} \\
(0.054) \\
\end{array}$ & $\begin{array}{l}6.693^{* * *} \\
(0.007) \\
\end{array}$ & $\begin{array}{l}3.751^{* * *} \\
(0.000)\end{array}$ & $\begin{array}{l}3.707^{* * *} \\
(0.000) \\
\end{array}$ \\
\hline Final estimation method & IV-GMM & IV-GMM & IV-GMM & IV-GMM \\
\hline IV tests (P-values): & & & & \\
\hline Endogeneity: FIRM_EQ & 0.087 & 0.033 & 0.000 & 0.000 \\
\hline EXPOS1 & 0.422 & 0.864 & 0.281 & 0.414 \\
\hline Underidentification & 0.000 & 0.000 & 0.000 & 0.000 \\
\hline Overidentifying restrictions & 0.665 & 0.457 & 0.183 & 0.346 \\
\hline Observations & 444 & 444 & 444 & 444 \\
\hline
\end{tabular}

P-values of coefficient estimates in parentheses, with $p<0.1^{*}, p<0.05^{* *}, p<0.01^{* * *}$.

Variable definitions as defined in Table 5 and SH_PROCT = revised anti-director rights index (Djankov et al. 2008), scaled to have a minimum of zero.

IV tests: endogeneity tested with $\mathrm{C}$ test (H0: exogeneity); underidentification tested using the Kleibergen-Paap rk LM statistic (H0: irrelevant instruments); overidentifying restrictions tested using Hansen test (H0: valid instruments). 
Table 8. Equity involvement in industrial firms, shareholder protection and commercial bank risk (Equation 4), cross-sectional over the period 2004-2008

\begin{tabular}{|c|c|c|c|c|}
\hline & \multicolumn{2}{|c|}{ Activity risk } & \multicolumn{2}{|c|}{ Insolvency risk } \\
\hline & SD_ROA & SD_ROE & LOG_Z & LOG_ZP \\
\hline PROP_CONTR & $\begin{array}{c}0.00621^{* * *} \\
(0.009)\end{array}$ & $\begin{array}{c}0.0894^{* * *} \\
(0.003)\end{array}$ & $\begin{array}{c}-0.0245^{* *} \\
(0.043)\end{array}$ & $\begin{array}{c}-0.0329^{* * *} \\
(0.007)\end{array}$ \\
\hline PROP_CONTR $\times$ SH_PROCT & $\begin{array}{c}-0.00215 \\
(0.127)\end{array}$ & $\begin{array}{c}-0.0299 \\
(0.111)\end{array}$ & $\begin{array}{c}0.00838 \\
(0.192)\end{array}$ & $\begin{array}{c}0.0131^{* *} \\
(0.044)\end{array}$ \\
\hline PROP_LHT & $\begin{array}{c}-0.0108^{* *} \\
(0.036)\end{array}$ & $\begin{array}{c}-0.135^{* *} \\
(0.031)\end{array}$ & $\begin{array}{c}0.0326^{* * *} \\
(0.002)\end{array}$ & $\begin{array}{c}0.0381^{* * *} \\
(0.000)\end{array}$ \\
\hline PROP_LHT $\times$ SH_PROCT & $\begin{array}{c}0.00512^{*} \\
(0.055)\end{array}$ & $\begin{array}{c}0.0663^{* *} \\
(0.047)\end{array}$ & $\begin{array}{c}-0.0180^{* * *} \\
(0.003)\end{array}$ & $\begin{array}{c}-0.0214^{* * *} \\
(0.001)\end{array}$ \\
\hline EXPOS1 & $\begin{array}{c}0.00457 \\
(0.620)\end{array}$ & $\begin{array}{l}0.0563 \\
(0.539)\end{array}$ & $\begin{array}{l}-0.0312 \\
(0.211)\end{array}$ & $\begin{array}{c}-0.0159 \\
(0.522)\end{array}$ \\
\hline NL_TA & $\begin{array}{c}0.00203 \\
(0.920)\end{array}$ & $\begin{array}{l}0.0306 \\
(0.894)\end{array}$ & $\begin{array}{l}0.0290 \\
(0.602)\end{array}$ & $\begin{array}{l}0.0401 \\
(0.478)\end{array}$ \\
\hline NONINT & $\begin{array}{c}0.00102 \\
(0.508)\end{array}$ & $\begin{array}{c}0.0382^{* *} \\
(0.031)\end{array}$ & $\begin{array}{c}-0.0112^{* * *} \\
(0.002)\end{array}$ & $\begin{array}{c}-0.0104^{* * *} \\
(0.004)\end{array}$ \\
\hline EQ_TA & $\begin{array}{c}0.0261^{* * * *} \\
(0.004)\end{array}$ & $\begin{array}{c}-0.0901{ }^{*} \\
(0.084)\end{array}$ & $\begin{array}{c}0.00853 \\
(0.514)\end{array}$ & $\begin{array}{c}0.00776 \\
(0.560)\end{array}$ \\
\hline LOG_TA & $\begin{array}{l}-0.0192 \\
(0.180)\end{array}$ & $\begin{array}{c}-0.00889 \\
(0.964)\end{array}$ & $\begin{array}{l}-0.0209 \\
(0.585)\end{array}$ & $\begin{array}{l}-0.0253 \\
(0.508)\end{array}$ \\
\hline GR_TA & $\begin{array}{c}0.000831 \\
(0.803)\end{array}$ & $\begin{array}{c}-0.00601 \\
(0.859)\end{array}$ & $\begin{array}{c}-0.00586 \\
(0.330)\end{array}$ & $\begin{array}{c}-0.00564 \\
(0.365)\end{array}$ \\
\hline ROA & $\begin{array}{c}0.128^{* * *} \\
(0.007)\end{array}$ & $\begin{array}{l}- \\
-\end{array}$ & $\begin{array}{l}- \\
-\end{array}$ & $\begin{array}{l}- \\
-\end{array}$ \\
\hline ROE & $\begin{array}{l}- \\
-\end{array}$ & $\begin{array}{c}0.00173 \\
(0.975)\end{array}$ & $\begin{array}{l}- \\
-\end{array}$ & $\begin{array}{l}- \\
-\end{array}$ \\
\hline SUP_REG & $\begin{array}{c}-0.0472^{* *} \\
(0.011)\end{array}$ & $\begin{array}{l}-0.496^{* *} \\
(0.011)\end{array}$ & $\begin{array}{l}0.248^{* * *} \\
(0.000)\end{array}$ & $\begin{array}{l}0.251^{* * *} \\
(0.000)\end{array}$ \\
\hline ACT_REST & $\begin{array}{c}0.00420 \\
(0.859)\end{array}$ & $\begin{array}{l}0.0393 \\
(0.896)\end{array}$ & $\begin{array}{l}-0.0550 \\
(0.300)\end{array}$ & $\begin{array}{l}-0.0742 \\
(0.167)\end{array}$ \\
\hline Constant & $\begin{array}{l}0.488^{*} \\
(0.073)\end{array}$ & $\begin{array}{c}7.636^{* * *} \\
(0.007)\end{array}$ & $\begin{array}{c}3.247^{* * * *} \\
(0.000)\end{array}$ & $\begin{array}{l}3.383^{* * * *} \\
(0.000)\end{array}$ \\
\hline Marginal effects: & & & & \\
\hline PROP_CONTR at Med(SH_PROCT) & - & - & - & $-0.0132^{* * *}$ \\
\hline PROP_CONTR at Max(SH_PROCT) & - & - & - & 0.00654 \\
\hline PROP_LHT at Med(SH_PROCT) & $-0.00311^{* *}$ & $-0.0357^{* *}$ & $0.00554^{* *}$ & $0.00593^{* *}$ \\
\hline PROP_LHT at Max(SH_PROCT) & 0.00456 & 0.0637 & $-0.0215^{* *}$ & $-0.0262^{* *}$ \\
\hline Final estimation method & IV-GMM & IV-GMM & IV-GMM & IV-GMM \\
\hline IV tests (P-values): & & & & \\
\hline Endogeneity : PROP_CONTR & 0.785 & 0.873 & 0.272 & 0.681 \\
\hline PROP_LHT & 0.053 & 0.030 & 0.000 & 0.000 \\
\hline EXPOS1 & 0.336 & 0.661 & 0.102 & 0.174 \\
\hline Underidentification & 0.000 & 0.000 & 0.000 & 0.000 \\
\hline Overidentifying restrictions & 0.599 & 0.897 & 0.283 & 0.501 \\
\hline Observations & 389 & 389 & 389 & 389 \\
\hline
\end{tabular}

P-values of coefficient estimates in parentheses, with $p<0.1^{*}, p<0.05^{* *}, p<0.01^{* * *}$. Variable definitions as defined in Table 6. IV tests: endogeneity tested with $C$ test (H0: exogeneity); underidentification tested using the Kleibergen-Paap rk LM statistic (H0: irrelevant instruments); overidentifying restrictions tested using Hansen test (H0: valid instruments). Significance of marginal effects determined using Wald tests. 
Table 9. Equity involvement in industrial firms and risk for commercial banks engaged in such equity investment (Equation 1), cross-sectional over the period 2004-2008

\begin{tabular}{|l|cc|cc|}
\hline & \multicolumn{2}{|c|}{ Activity risk } & \multicolumn{2}{c|}{ Insolvency risk } \\
& SD_ROA & SD_ROE & LOG_Z & LOG_ZP \\
\hline FIRM_EQ & 0.00135 & $0.0242^{* *}$ & $-0.00513^{* *}$ & $-0.00530^{* * *}$ \\
EXPOS1 & $(0.115)$ & $(0.023)$ & $(0.014)$ & $(0.006)$ \\
NL_TA & 0.0109 & 0.0778 & $-0.0369^{* *}$ & $-0.0232^{*}$ \\
& $(0.181)$ & $(0.299)$ & $(0.027)$ & $(0.097)$ \\
NONINT & -0.00312 & -0.0703 & 0.0251 & 0.0427 \\
& $(0.868)$ & $(0.786)$ & $(0.590)$ & $(0.328)$ \\
EQ_TA & 0.000827 & $0.0358^{* *}$ & $-0.00955^{* * *}$ & $-0.00936^{* * *}$ \\
& $(0.616)$ & $(0.045)$ & $(0.002)$ & $(0.001)$ \\
LOG_TA & $0.0164^{*}$ & $-0.0920^{* *}$ & $0.0143^{*}$ & $0.0151^{* *}$ \\
GR_TA & $(0.057)$ & $(0.019)$ & $(0.063)$ & $(0.041)$ \\
ROA & -0.0229 & 0.105 & -0.0207 & -0.0275 \\
& $(0.131)$ & $(0.576)$ & $(0.526)$ & $(0.367)$ \\
ROE & 0.00258 & 0.0139 & -0.00653 & -0.00645 \\
& $(0.325)$ & $(0.635)$ & $(0.172)$ & $(0.155)$ \\
SUP_REG & $0.151^{* * *}$ & - & - & - \\
ACT_REST & $(0.003)$ & - & - & - \\
EXPOS1 & - & 0.00253 & - & - \\
Constant & - & $(0.965)$ & - & - \\
& $-0.0390^{* *}$ & $-0.334^{*}$ & $0.133^{* * *}$ & $0.142^{* * *}$ \\
Final estimation method & $(0.028)$ & $(0.098)$ & $(0.007)$ & $(0.003)$ \\
IV tests (P-values) & $-0.0409^{* * *}$ & $-0.549^{* * *}$ & $0.0801^{* *}$ & $0.0724^{* *}$ \\
Endogeneity: FIRM_EQ & $(0.007)$ & $(0.002)$ & $(0.018)$ & $(0.029)$ \\
& $0.808^{* * *}$ & $9.678^{* * *}$ & $2.698^{* * *}$ & $2.709^{* * *}$ \\
Observations & $(0.001)$ & $(0.001)$ & $(0.000)$ & $(0.000)$ \\
\hline
\end{tabular}

P-values of coefficient estimates in parentheses, with $p<0.1^{*}, p<0.05^{* *}, p<0.01^{* * *}$.

Variable definitions: as defined in Table 5.

IV tests: endogeneity tested with C test (H0: exogeneity). 
Table 10. Equity involvement in industrial firms and risk for commercial banks engaged in such equity investment (Equation 2), cross-sectional over the period 2004-2008

\begin{tabular}{|c|c|c|c|c|}
\hline & \multicolumn{2}{|c|}{ Activity risk } & \multicolumn{2}{|c|}{ Insolvency risk } \\
\hline & SD_ROA & SD_ROE & LOG_Z & LOG_ZP \\
\hline PROP_CONTR & $\begin{array}{c}0.00198^{* *} \\
(0.019)\end{array}$ & $\begin{array}{c}0.0354^{* * *} \\
(0.000)\end{array}$ & $\begin{array}{c}-0.00757^{* * *} \\
(0.000)\end{array}$ & $\begin{array}{c}-0.00752^{* * *} \\
(0.000)\end{array}$ \\
\hline PROP_LHT & $\begin{array}{c}-0.00201^{* * *} \\
(0.006)\end{array}$ & $\begin{array}{c}-0.0179^{* *} \\
(0.019)\end{array}$ & $\begin{array}{c}0.00426^{* *} \\
(0.013)\end{array}$ & $\begin{array}{c}0.00426^{* *} \\
(0.011)\end{array}$ \\
\hline EXPOS1 & $\begin{array}{c}0.00123 \\
(0.894)\end{array}$ & $\begin{array}{l}0.0590 \\
(0.475)\end{array}$ & $\begin{array}{c}-0.0284 \\
(0.117)\end{array}$ & $\begin{array}{l}-0.0155 \\
(0.328)\end{array}$ \\
\hline NL_TA & $\begin{array}{c}0.00576 \\
(0.750)\end{array}$ & $\begin{array}{c}0.150 \\
(0.460)\end{array}$ & $\begin{array}{c}-0.00168 \\
(0.970)\end{array}$ & $\begin{array}{l}0.0166 \\
(0.690)\end{array}$ \\
\hline NONINT & $\begin{array}{c}0.000874 \\
(0.584)\end{array}$ & $\begin{array}{c}0.0374^{* *} \\
(0.038)\end{array}$ & $\begin{array}{c}-0.00951^{* * *} \\
(0.002)\end{array}$ & $\begin{array}{c}-0.00929^{* * *} \\
(0.002)\end{array}$ \\
\hline EQ_TA & $\begin{array}{c}0.0279^{* * *} \\
(0.005)\end{array}$ & $\begin{array}{c}-0.0853^{*} \\
(0.093)\end{array}$ & $\begin{array}{l}0.0137 \\
(0.232)\end{array}$ & $\begin{array}{l}0.0136 \\
(0.226)\end{array}$ \\
\hline LOG_TA & $\begin{array}{l}-0.0131 \\
(0.351)\end{array}$ & $\begin{array}{l}0.0866 \\
(0.649)\end{array}$ & $\begin{array}{l}-0.0120 \\
(0.726)\end{array}$ & $\begin{array}{c}-0.0187 \\
(0.559)\end{array}$ \\
\hline GR_TA & $\begin{array}{c}0.00171 \\
(0.498)\end{array}$ & $\begin{array}{c}0.00449 \\
(0.878)\end{array}$ & $\begin{array}{c}-0.00561 \\
(0.234)\end{array}$ & $\begin{array}{c}-0.00528 \\
(0.242)\end{array}$ \\
\hline ROA & $\begin{array}{l}0.141^{* * * *} \\
(0.003)\end{array}$ & - & $\begin{array}{l}- \\
-\end{array}$ & $\begin{array}{l}- \\
-\end{array}$ \\
\hline ROE & $\begin{array}{l}- \\
-\end{array}$ & $\begin{array}{l}0.0202 \\
(0.724)\end{array}$ & - & $\begin{array}{l}- \\
-\end{array}$ \\
\hline SUP_REG & $\begin{array}{c}-0.0362^{* *} \\
(0.038)\end{array}$ & $\begin{array}{l}-0.336^{*} \\
(0.087)\end{array}$ & $\begin{array}{l}0.125^{* *} \\
(0.010)\end{array}$ & $\begin{array}{l}0.133^{* * *} \\
(0.004)\end{array}$ \\
\hline ACT_REST & $\begin{array}{c}-0.0433^{* * *} \\
(0.003)\end{array}$ & $\begin{array}{c}-0.565^{* * *} \\
(0.001)\end{array}$ & $\begin{array}{c}0.0773^{* *} \\
(0.021)\end{array}$ & $\begin{array}{c}0.0703^{* *} \\
(0.030)\end{array}$ \\
\hline Constant & $\begin{array}{c}0.744^{* * *} \\
(0.005) \\
\end{array}$ & $\begin{array}{l}10.28^{* * *} \\
(0.001)\end{array}$ & $\begin{array}{c}2.565^{* * *} \\
(0.000)\end{array}$ & $\begin{array}{c}2.566^{* * *} \\
(0.000)\end{array}$ \\
\hline Final estimation method & OLS & OLS & OLS & OLS \\
\hline $\begin{array}{l}\text { IV tests (P-values): } \\
\text { Endogeneity : PROP_CONTR }\end{array}$ & 0.170 & 0.316 & 0.762 & 0.266 \\
\hline PROP_LHT & 0.196 & 0.152 & 0.0786 & 0.512 \\
\hline EXPOS1 & 0.247 & 0.632 & 0.630 & 0.489 \\
\hline Observations & 353 & 353 & 353 & 353 \\
\hline
\end{tabular}

P-values of coefficient estimates in parentheses, with $p<0.1^{*}, p<0.05^{* *}, p<0.01^{* * *}$.

Variable definitions: as defined in Table 6.

IV tests: endogeneity tested with $\mathrm{C}$ test (H0: exogeneity). 
Table 11. Equity involvement in industrial firms, non-linearities and risk for commercial banks, cross-sectional over the period 2004-2008

\begin{tabular}{|c|c|c|c|c|}
\hline & \multicolumn{2}{|c|}{ Activity risk } & \multicolumn{2}{|c|}{ Insolvency risk } \\
\hline & SD_ROA & SD_ROE & LOG_Z & LOG_ZP \\
\hline FIRM_EQ & $\begin{array}{c}0.00318^{* * *} \\
(0.002)\end{array}$ & $\begin{array}{c}0.0380^{* * *} \\
(0.001)\end{array}$ & $\begin{array}{c}-0.0296^{* * *} \\
(0.004)\end{array}$ & $\begin{array}{c}-0.0321^{* * *} \\
(0.002)\end{array}$ \\
\hline FIRM_EQ_CSQ & $\begin{array}{c}-0.0000620^{*} \\
(0.059)\end{array}$ & $\begin{array}{c}-0.000336 \\
(0.324)\end{array}$ & $\begin{array}{c}-0.000214 \\
(0.628)\end{array}$ & $\begin{array}{c}-0.000209 \\
(0.653)\end{array}$ \\
\hline EXPOS1 & $\begin{array}{c}0.00549 \\
(0.265)\end{array}$ & $\begin{array}{l}0.0586 \\
(0.214)\end{array}$ & $\begin{array}{c}-0.0162 \\
(0.402)\end{array}$ & $\begin{array}{c}-0.00696 \\
(0.747)\end{array}$ \\
\hline NL_TA & $\begin{array}{l}-0.0189 \\
(0.335)\end{array}$ & $\begin{array}{l}-0.163 \\
(0.456)\end{array}$ & $\begin{array}{c}0.0151 \\
(0.767)\end{array}$ & $\begin{array}{l}0.0318 \\
(0.529)\end{array}$ \\
\hline NONINT & $\begin{array}{c}0.00112 \\
(0.405)\end{array}$ & $\begin{array}{c}0.0360^{* *} \\
(0.013)\end{array}$ & $\begin{array}{c}-0.0110^{* * *} \\
(0.001)\end{array}$ & $\begin{array}{c}-0.0102^{* * *} \\
(0.002)\end{array}$ \\
\hline EQ_TA & $\begin{array}{c}0.0164^{* *} \\
(0.017)\end{array}$ & $\begin{array}{c}-0.0873^{* * *} \\
(0.005)\end{array}$ & $\begin{array}{l}0.0115 \\
(0.324)\end{array}$ & $\begin{array}{l}0.0139 \\
(0.230)\end{array}$ \\
\hline LOG_TA & $\begin{array}{c}-0.0323^{* *} \\
(0.030)\end{array}$ & $\begin{array}{l}0.0759 \\
(0.655)\end{array}$ & $\begin{array}{l}0.0271 \\
(0.663)\end{array}$ & $\begin{array}{l}0.0368 \\
(0.567)\end{array}$ \\
\hline GR_TA & $\begin{array}{c}0.00338 \\
(0.298)\end{array}$ & $\begin{array}{l}0.0207 \\
(0.463)\end{array}$ & $\begin{array}{c}-0.0101^{*} \\
(0.054)\end{array}$ & $\begin{array}{c}-0.00959^{*} \\
(0.059)\end{array}$ \\
\hline ROA & $\begin{array}{l}0.125^{* * *} \\
(0.009)\end{array}$ & $\begin{array}{l}- \\
-\end{array}$ & $\begin{array}{l}- \\
-\end{array}$ & $\begin{array}{l}- \\
-\end{array}$ \\
\hline ROE & $\begin{array}{l}- \\
-\end{array}$ & $\begin{array}{c}-0.00397 \\
(0.940)\end{array}$ & $\begin{array}{l}- \\
-\end{array}$ & $\begin{array}{l}- \\
-\end{array}$ \\
\hline SUP_REG & $\begin{array}{l}-0.0232 \\
(0.192)\end{array}$ & $\begin{array}{c}-0.312^{* *} \\
(0.044)\end{array}$ & $\begin{array}{c}0.246^{* * *} \\
(0.000)\end{array}$ & $\begin{array}{c}0.231^{* * *} \\
(0.000)\end{array}$ \\
\hline ACT_REST & $\begin{array}{l}-0.0174 \\
(0.297)\end{array}$ & $\begin{array}{l}-0.371^{* *} \\
(0.021)\end{array}$ & $\begin{array}{c}-0.000895 \\
(0.986)\end{array}$ & $\begin{array}{l}-0.0288 \\
(0.585)\end{array}$ \\
\hline Constant & $\begin{array}{l}0.571^{* *} \\
(0.018)\end{array}$ & $\begin{array}{c}7.898^{* * *} \\
(0.001) \\
\end{array}$ & $\begin{array}{c}3.430^{* * *} \\
(0.000) \\
\end{array}$ & $\begin{array}{l}3.673^{* * *} \\
(0.000) \\
\end{array}$ \\
\hline Final estimation method & OLS & OLS & IV-GMM & IV-GMM \\
\hline IV tests (P-values): & & & & \\
\hline Endogeneity: FIRM_EQ & 0.267 & 0.095 & 0.002 & 0.000 \\
\hline EXPOS1 & 0.963 & 0.780 & 0.477 & 0.445 \\
\hline Underidentification & - & - & 0.070 & 0.070 \\
\hline Overidentifying restrictions & - & - & 0.142 & 0.268 \\
\hline Observations & 444 & 444 & 444 & 444 \\
\hline
\end{tabular}

P-values of coefficient estimates in parentheses, with $p<0.1^{*}, p<0.05^{* *}, p<0.01^{* * *}$.

Variable definitions: as defined in Table 5 and FIRM_EQ_CSQ = demeaned square of FIRM_EQ.

IV tests: endogeneity tested with $\mathrm{C}$ test (H0: exogeneity); underidentification tested using the Kleibergen-Paap rk LM statistic (H0: irrelevant instruments); overidentifying restrictions tested using Hansen test (H0: valid instruments). 
Table 12. Equity involvement in industrial firms and risk for large commercial banks (Equation 1), cross-sectional over the period 2004-2008

\begin{tabular}{|c|c|c|c|c|}
\hline & \multicolumn{2}{|c|}{ Activity risk } & \multicolumn{2}{|c|}{ Insolvency risk } \\
\hline & SD_ROA & SD_ROE & LOG_Z & LOG_ZP \\
\hline FIRM_EQ & $\begin{array}{c}0.00736^{* *} \\
(0.043)\end{array}$ & $\begin{array}{l}0.114^{* *} \\
(0.028)\end{array}$ & $\begin{array}{c}-0.0333^{* * *} \\
(0.003)\end{array}$ & $\begin{array}{c}-0.0342^{* * *} \\
(0.002)\end{array}$ \\
\hline EXPOS1 & $\begin{array}{c}0.00177 \\
(0.896)\end{array}$ & $\begin{array}{l}0.0666 \\
(0.670)\end{array}$ & $\begin{array}{r}-0.0125 \\
(0.713)\end{array}$ & $\begin{array}{l}0.0180 \\
(0.576)\end{array}$ \\
\hline NL_TA & $\begin{array}{c}0.00924 \\
(0.602)\end{array}$ & $\begin{array}{c}0.347 \\
(0.191)\end{array}$ & $\begin{array}{c}-0.0555 \\
(0.398)\end{array}$ & $\begin{array}{l}-0.0191 \\
(0.764)\end{array}$ \\
\hline NONINT & $\begin{array}{c}0.00262^{* *} \\
(0.013)\end{array}$ & $\begin{array}{c}0.0491^{* * *} \\
(0.006)\end{array}$ & $\begin{array}{c}-0.0101^{* * *} \\
(0.006)\end{array}$ & $\begin{array}{c}-0.0105^{* * *} \\
(0.004)\end{array}$ \\
\hline EQ_TA & $\begin{array}{c}0.0303^{* *} \\
(0.031)\end{array}$ & $\begin{array}{r}-0.0367 \\
(0.706)\end{array}$ & $\begin{array}{c}0.00959 \\
(0.745)\end{array}$ & $\begin{array}{l}0.0142 \\
(0.624)\end{array}$ \\
\hline LOG_TA & $\begin{array}{c}-0.000617 \\
(0.969)\end{array}$ & $\begin{array}{c}0.306 \\
(0.243)\end{array}$ & $\begin{array}{c}-0.0235 \\
(0.659)\end{array}$ & $\begin{array}{c}-0.0410 \\
(0.408)\end{array}$ \\
\hline GR_TA & $\begin{array}{c}-0.00180 \\
(0.344)\end{array}$ & $\begin{array}{c}-0.0222 \\
(0.372)\end{array}$ & $\begin{array}{c}-0.00245 \\
(0.651)\end{array}$ & $\begin{array}{c}-0.00231 \\
(0.659)\end{array}$ \\
\hline ROA & $\begin{array}{l}0.0725 \\
(0.324)\end{array}$ & $\begin{array}{l}- \\
-\end{array}$ & $\begin{array}{l}- \\
-\end{array}$ & $\begin{array}{l}- \\
-\end{array}$ \\
\hline ROE & $\begin{array}{l}- \\
-\end{array}$ & $\begin{array}{l}0.0599 \\
(0.257)\end{array}$ & $\begin{array}{l}- \\
-\end{array}$ & $\begin{array}{l}- \\
-\end{array}$ \\
\hline SUP_REG & $\begin{array}{c}-0.0548^{* *} \\
(0.012)\end{array}$ & $\begin{array}{c}-0.817^{* * * *} \\
(0.007)\end{array}$ & $\begin{array}{l}0.213^{* * * *} \\
(0.004)\end{array}$ & $\begin{array}{l}0.204^{* * * *} \\
(0.006)\end{array}$ \\
\hline ACT_REST & $\begin{array}{c}-0.0258 \\
(0.165)\end{array}$ & $\begin{array}{l}-0.431^{*} \\
(0.084)\end{array}$ & $\begin{array}{l}0.0193 \\
(0.745)\end{array}$ & $\begin{array}{c}-0.00408 \\
(0.945)\end{array}$ \\
\hline Constant & $\begin{array}{c}0.315 \\
(0.340) \\
\end{array}$ & $\begin{array}{c}5.301 \\
(0.208)\end{array}$ & $\begin{array}{c}3.766^{* * *} \\
(0.000)\end{array}$ & $\begin{array}{c}4.121^{* * *} \\
(0.000)\end{array}$ \\
\hline Final estimation method & IV-GMM & IV-GMM & IV-GMM & IV-GMM \\
\hline IV tests (P-values): & & & & \\
\hline Endogeneity: FIRM_EQ & 0.065 & 0.063 & 0.000 & 0.000 \\
\hline EXPOS1 & 0.759 & 0.565 & 0.751 & 0.938 \\
\hline Underidentification & 0.014 & 0.015 & 0.015 & 0.015 \\
\hline Overidentifying restrictions & 0.795 & 0.431 & 0.908 & 0.937 \\
\hline Observations & 256 & 256 & 256 & 256 \\
\hline
\end{tabular}

P-values of coefficient estimates in parentheses, with $p<0.1^{*}, p<0.05^{* *}, p<0.01^{* * *}$.

Variable definitions: as defined in Table 5.

IV tests: endogeneity tested with C test (H0: exogeneity); underidentification tested using the Kleibergen-Paap rk LM statistic (H0: irrelevant instruments); overidentifying restrictions tested using Hansen test (H0: valid instruments). 
Table 13. Equity involvement in industrial firms and risk for small commercial banks (Equation 1), cross-sectional over the period 2004-2008

\begin{tabular}{|c|c|c|c|c|}
\hline & \multicolumn{2}{|c|}{ Activity risk } & \multicolumn{2}{|c|}{ Insolvency risk } \\
\hline & SD_ROA & SD_ROE & LOG_Z & LOG_ZP \\
\hline FIRM_EQ & $\begin{array}{c}0.00200 \\
(0.134)\end{array}$ & $\begin{array}{c}0.0386^{* *} \\
(0.016)\end{array}$ & $\begin{array}{c}-0.0471^{* * *} \\
(0.001)\end{array}$ & $\begin{array}{c}-0.0479^{* * *} \\
(0.001)\end{array}$ \\
\hline EXPOS1 & $\begin{array}{c}0.000803 \\
(0.849)\end{array}$ & $\begin{array}{c}0.00269 \\
(0.956)\end{array}$ & $\begin{array}{c}0.000789 \\
(0.977)\end{array}$ & $\begin{array}{c}0.00183 \\
(0.950)\end{array}$ \\
\hline NL_TA & $\begin{array}{l}-0.0387 \\
(0.279)\end{array}$ & $\begin{array}{c}-0.503 \\
(0.157)\end{array}$ & $\begin{array}{l}0.0385 \\
(0.647)\end{array}$ & $\begin{array}{l}0.0248 \\
(0.777)\end{array}$ \\
\hline NONINT & $\begin{array}{c}0.000219 \\
(0.927)\end{array}$ & $\begin{array}{c}0.0256 \\
(0.213)\end{array}$ & $\begin{array}{c}-0.00828 \\
(0.144)\end{array}$ & $\begin{array}{c}-0.00831 \\
(0.135)\end{array}$ \\
\hline EQ_TA & $\begin{array}{c}0.00923 \\
(0.184)\end{array}$ & $\begin{array}{c}-0.119^{* * *} \\
(0.004)\end{array}$ & $\begin{array}{c}0.00686 \\
(0.585)\end{array}$ & $\begin{array}{c}0.00989 \\
(0.449)\end{array}$ \\
\hline LOG_TA & $\begin{array}{l}-0.156^{* *} \\
(0.020)\end{array}$ & $\begin{array}{l}-0.255 \\
(0.647)\end{array}$ & $\begin{array}{c}0.163 \\
(0.330)\end{array}$ & $\begin{array}{c}0.202 \\
(0.233)\end{array}$ \\
\hline GR_TA & $\begin{array}{c}0.00789 \\
(0.160)\end{array}$ & $\begin{array}{l}0.0484 \\
(0.279)\end{array}$ & $\begin{array}{c}-0.0124 \\
(0.160)\end{array}$ & $\begin{array}{l}-0.0138 \\
(0.109)\end{array}$ \\
\hline ROA & $\begin{array}{l}0.137^{* *} \\
(0.016)\end{array}$ & $\begin{array}{l}- \\
-\end{array}$ & $\begin{array}{l}- \\
-\end{array}$ & $\begin{array}{l}- \\
-\end{array}$ \\
\hline ROE & $\begin{array}{l}- \\
-\end{array}$ & $\begin{array}{l}-0.0424 \\
(0.584)\end{array}$ & - & $\begin{array}{l}- \\
-\end{array}$ \\
\hline SUP_REG & $\begin{array}{l}-0.0295 \\
(0.200)\end{array}$ & $\begin{array}{l}-0.285 \\
(0.106)\end{array}$ & $\begin{array}{l}0.275^{* * *} \\
(0.000)\end{array}$ & $\begin{array}{c}0.281^{* * *} \\
(0.000)\end{array}$ \\
\hline ACT_REST & $\begin{array}{l}0.0454 \\
(0.184)\end{array}$ & $\begin{array}{c}0.272 \\
(0.451)\end{array}$ & $\begin{array}{l}-0.163^{*} \\
(0.083)\end{array}$ & $\begin{array}{l}-0.167^{*} \\
(0.082)\end{array}$ \\
\hline Constant & $\begin{array}{c}0.870^{*} \\
(0.055)\end{array}$ & $\begin{array}{c}5.383 \\
(0.280) \\
\end{array}$ & $\begin{array}{l}3.830^{* * *} \\
(0.002)\end{array}$ & $\begin{array}{c}3.570^{* * *} \\
(0.004)\end{array}$ \\
\hline Final estimation method & OLS & OLS & IV-GMM & IV-GMM \\
\hline IV tests (P-values): & & & & \\
\hline Endogeneity: FIRM_EQ & 0.324 & 0.268 & 0.002 & 0.001 \\
\hline EXPOS1 & 0.582 & 0.211 & 0.413 & 0.446 \\
\hline Underidentification & - & - & 0.034 & 0.034 \\
\hline Overidentifying restrictions & - & - & 0.876 & 0.793 \\
\hline Observations & 188 & 188 & 188 & 188 \\
\hline
\end{tabular}

P-values of coefficient estimates in parentheses, with $p<0.1^{*}, p<0.05^{* *}, p<0.01^{* * *}$.

Variable definitions: as defined in Table 5.

IV tests: endogeneity tested with C test (H0: exogeneity); underidentification tested using the Kleibergen-Paap rk LM statistic (H0: irrelevant instruments); overidentifying restrictions tested using Hansen test (H0: valid instruments). 
Table 14. Equity involvement in industrial firms and risk for large commercial banks (Equation 2), cross-sectional over the period 2004-2008

\begin{tabular}{|c|c|c|c|c|}
\hline & \multicolumn{2}{|c|}{ Activity risk } & \multicolumn{2}{|c|}{ Insolvency risk } \\
\hline & SD_ROA & SD_ROE & LOG_Z & LOG_ZP \\
\hline PROP_CONTR & $\begin{array}{c}0.0132^{* * *} \\
(0.000)\end{array}$ & $\begin{array}{c}0.195^{* * *} \\
(0.000)\end{array}$ & $\begin{array}{c}-0.0374^{* * *} \\
(0.000)\end{array}$ & $\begin{array}{c}-0.0397^{* * *} \\
(0.001)\end{array}$ \\
\hline PROP_LHT & $\begin{array}{c}-0.00310^{* * *} \\
(0.003)\end{array}$ & $\begin{array}{c}-0.0553^{* * *} \\
(0.001)\end{array}$ & $\begin{array}{c}0.0107^{* * *} \\
(0.004)\end{array}$ & $\begin{array}{c}0.0111^{* * *} \\
(0.004)\end{array}$ \\
\hline EXPOS1 & $\begin{array}{c}-0.000716 \\
(0.952)\end{array}$ & $\begin{array}{l}-0.0261 \\
(0.859)\end{array}$ & $\begin{array}{c}-0.00676 \\
(0.831)\end{array}$ & $\begin{array}{l}0.0230 \\
(0.495)\end{array}$ \\
\hline NL_TA & $\begin{array}{c}0.0419^{* *} \\
(0.037)\end{array}$ & $\begin{array}{c}0.818^{* * *} \\
(0.007)\end{array}$ & $\begin{array}{c}-0.109 \\
(0.117)\end{array}$ & $\begin{array}{c}-0.0809 \\
(0.255)\end{array}$ \\
\hline NONINT & $\begin{array}{c}0.00170 \\
(0.127)\end{array}$ & $\begin{array}{c}0.0405^{* *} \\
(0.037)\end{array}$ & $\begin{array}{c}-0.00872^{* *} \\
(0.027)\end{array}$ & $\begin{array}{c}-0.00920^{* *} \\
(0.026)\end{array}$ \\
\hline EQ_TA & $\begin{array}{l}0.0126 \\
(0.321)\end{array}$ & $\begin{array}{l}-0.113 \\
(0.239)\end{array}$ & $\begin{array}{l}0.0335 \\
(0.229)\end{array}$ & $\begin{array}{l}0.0357 \\
(0.235)\end{array}$ \\
\hline LOG_TA & $\begin{array}{c}0.00659 \\
(0.660)\end{array}$ & $\begin{array}{c}0.394 \\
(0.136)\end{array}$ & $\begin{array}{l}-0.0521 \\
(0.310)\end{array}$ & $\begin{array}{l}-0.0669 \\
(0.197)\end{array}$ \\
\hline GR_TA & $\begin{array}{c}-0.00435^{*} \\
(0.052)\end{array}$ & $\begin{array}{c}-0.0684^{* * *} \\
(0.019)\end{array}$ & $\begin{array}{c}0.00760 \\
(0.207)\end{array}$ & $\begin{array}{c}0.00695 \\
(0.304)\end{array}$ \\
\hline ROA & $\begin{array}{l}0.215^{* * *} \\
(0.002)\end{array}$ & $\begin{array}{l}- \\
-\end{array}$ & - & - \\
\hline ROE & $\begin{array}{l}- \\
-\end{array}$ & $\begin{array}{l}0.0864 \\
(0.108)\end{array}$ & $\begin{array}{l}- \\
-\end{array}$ & $\begin{array}{l}- \\
-\end{array}$ \\
\hline SUP_REG & $\begin{array}{c}-0.0786^{* * *} \\
(0.001)\end{array}$ & $\begin{array}{c}-1.096^{* * *} \\
(0.001)\end{array}$ & $\begin{array}{l}0.195^{* * *} \\
(0.006)\end{array}$ & $\begin{array}{c}0.198^{* * *} \\
(0.009)\end{array}$ \\
\hline ACT_REST & $\begin{array}{c}0.00378 \\
(0.833)\end{array}$ & $\begin{array}{l}-0.123 \\
(0.654)\end{array}$ & $\begin{array}{l}-0.0225 \\
(0.722)\end{array}$ & $\begin{array}{l}-0.0431 \\
(0.531)\end{array}$ \\
\hline Constant & $\begin{array}{c}0.133 \\
(0.685)\end{array}$ & $\begin{array}{c}4.119 \\
(0.381)\end{array}$ & $\begin{array}{l}3.828^{* * * *} \\
(0.000)\end{array}$ & $\begin{array}{l}4.127^{* * * *} \\
(0.000)\end{array}$ \\
\hline Final estimation method & IV-GMM & IV-GMM & IV-GMM & IV-GMM \\
\hline $\begin{array}{l}\text { IV tests (P-values): } \\
\text { Endogeneity : PROP_CONTR }\end{array}$ & 0.002 & 0.003 & 0.002 & 0.001 \\
\hline PROP_LHT & 0.989 & 0.656 & 0.209 & 0.382 \\
\hline EXPOS1 & 0.543 & 0.813 & 0.746 & 0.860 \\
\hline Underidentification & 0.0167 & 0.0176 & 0.0197 & 0.0197 \\
\hline Overidentifying restrictions & 0.189 & 0.152 & 0.243 & 0.428 \\
\hline Observations & 234 & 234 & 234 & 234 \\
\hline
\end{tabular}

P-values of coefficient estimates in parentheses, with $p<0.1^{*}, p<0.05^{* *}, p<0.01^{* * *}$.

Variable definitions: as defined in Table 6.

IV tests: endogeneity tested with C test (H0: exogeneity); underidentification tested using the Kleibergen-Paap rk LM statistic (H0: irrelevant instruments); overidentifying restrictions tested using Hansen test (H0: valid instruments). 
Table 15. Equity involvement in industrial firms and risk for small commercial banks (Equation 2), cross-sectional over the period 2004-2008

\begin{tabular}{|c|c|c|c|c|}
\hline & \multicolumn{2}{|c|}{ Activity risk } & \multicolumn{2}{|c|}{ Insolvency risk } \\
\hline & SD_ROA & SD_ROE & LOG_Z & LOG_ZP \\
\hline PROP_CONTR & $\begin{array}{c}0.00276^{*} \\
(0.059)\end{array}$ & $\begin{array}{c}0.0454^{* * *} \\
(0.010)\end{array}$ & $\begin{array}{c}-0.0103^{* * * *} \\
(0.002)\end{array}$ & $\begin{array}{c}-0.0103^{* * * *} \\
(0.001)\end{array}$ \\
\hline PROP_LHT & $\begin{array}{c}-0.000732 \\
(0.460)\end{array}$ & $\begin{array}{c}0.00111 \\
(0.909)\end{array}$ & $\begin{array}{c}-0.00320 \\
(0.163)\end{array}$ & $\begin{array}{c}-0.00333 \\
(0.143)\end{array}$ \\
\hline EXPOS1 & $\begin{array}{c}-0.00519 \\
(0.649)\end{array}$ & $\begin{array}{l}-0.0601 \\
(0.496)\end{array}$ & $\begin{array}{l}-0.0134 \\
(0.604)\end{array}$ & $\begin{array}{c}-0.0141 \\
(0.591)\end{array}$ \\
\hline NL_TA & $\begin{array}{c}-0.0391 \\
(0.394)\end{array}$ & $\begin{array}{l}-0.378 \\
(0.285)\end{array}$ & $\begin{array}{l}0.0905 \\
(0.255)\end{array}$ & $\begin{array}{l}0.0707 \\
(0.388)\end{array}$ \\
\hline NONINT & $\begin{array}{c}-0.000288 \\
(0.913)\end{array}$ & $\begin{array}{l}0.0303 \\
(0.209)\end{array}$ & $\begin{array}{c}-0.0143^{* * *} \\
(0.007)\end{array}$ & $\begin{array}{c}-0.0136 \\
(0.006)\end{array}$ \\
\hline EQ_TA & $\begin{array}{l}0.0188 \\
(0.121)\end{array}$ & $\begin{array}{c}-0.161^{* *} \\
(0.026)\end{array}$ & $\begin{array}{l}0.0190 \\
(0.344)\end{array}$ & $\begin{array}{l}0.0188 \\
(0.338)\end{array}$ \\
\hline LOG_TA & $\begin{array}{l}-0.146^{* *} \\
(0.030)\end{array}$ & $\begin{array}{l}-0.709 \\
(0.277)\end{array}$ & $\begin{array}{l}0.0597 \\
(0.721)\end{array}$ & $\begin{array}{l}0.0872 \\
(0.595)\end{array}$ \\
\hline GR_TA & $\begin{array}{c}0.00909 \\
(0.148)\end{array}$ & $\begin{array}{l}0.0568 \\
(0.289)\end{array}$ & $\begin{array}{c}-0.0194^{* * *} \\
(0.030)\end{array}$ & $\begin{array}{c}-0.0213^{* *} \\
(0.015)\end{array}$ \\
\hline ROA & $\begin{array}{l}0.131^{* *} \\
(0.029)\end{array}$ & - & $\begin{array}{l}- \\
-\end{array}$ & $\begin{array}{l}- \\
-\end{array}$ \\
\hline ROE & $\begin{array}{l}- \\
-\end{array}$ & $\begin{array}{l}-0.0205 \\
(0.786)\end{array}$ & $\begin{array}{l}- \\
-\end{array}$ & $\begin{array}{l}- \\
-\end{array}$ \\
\hline SUP_REG & $\begin{array}{l}-0.0286 \\
(0.325)\end{array}$ & $\begin{array}{l}-0.284 \\
(0.204)\end{array}$ & $\begin{array}{c}0.293^{* * *} \\
(0.000)\end{array}$ & $\begin{array}{c}0.307^{* * *} \\
(0.000)\end{array}$ \\
\hline ACT_REST & $\begin{array}{l}0.0359 \\
(0.338)\end{array}$ & $\begin{array}{c}0.184 \\
(0.609)\end{array}$ & $\begin{array}{l}-0.0937 \\
(0.231)\end{array}$ & $\begin{array}{l}-0.0896 \\
(0.264)\end{array}$ \\
\hline Constant & $\begin{array}{c}0.809 \\
(0.127)\end{array}$ & $\begin{array}{c}8.541 \\
(0.129)\end{array}$ & $\begin{array}{l}3.296^{* * *} \\
(0.005)\end{array}$ & $\begin{array}{l}2.979^{* * *} \\
(0.009)\end{array}$ \\
\hline Final estimation method & OLS & OLS & OLS & OLS \\
\hline $\begin{array}{l}\text { IV tests (P-values): } \\
\text { Endogeneity : PROP_CONTR }\end{array}$ & 0.254 & 0.962 & 0.125 & 0.057 \\
\hline PROP_LHT & 0.811 & 0.316 & 0.213 & 0.234 \\
\hline EXPOS1 & 0.279 & 0.144 & 0.174 & 0.116 \\
\hline Observations & 155 & 155 & 155 & 155 \\
\hline
\end{tabular}

P-values of coefficient estimates in parentheses, with $p<0.1^{*}, p<0.05^{* *}, p<0.01^{* * *}$.

Variable definitions: as defined in Table 6.

IV tests: endogeneity tested with $\mathrm{C}$ test (H0: exogeneity). 


\section{Appendix}

Table A1. Correlation matrix

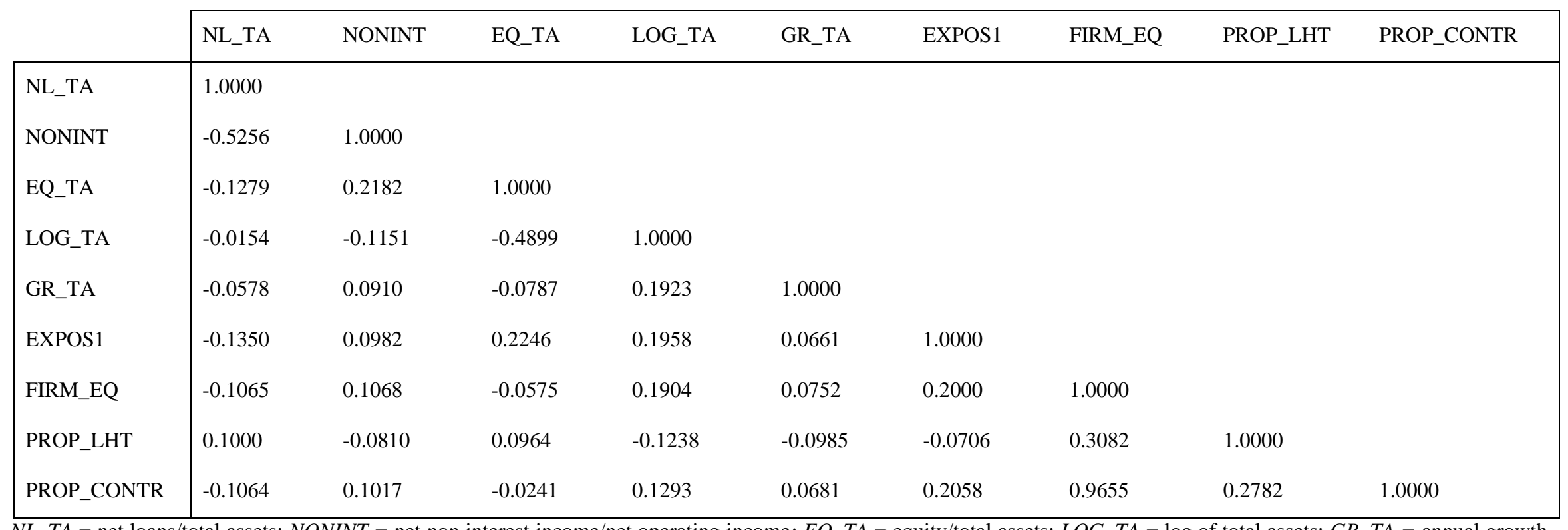

$N L \_T A=$ net loans/total assets; NONINT = net non interest income/net operating income; $E Q \_T A=$ equity/total assets; LOG_TA = log of total assets; GR_TA = annual growth rate of total assets; $E X P O S 1$ = ratio of total equity investments (in financial and non-financial firms) to total assets; FIRM_EQ = mean of equity investments as percentage of individual industrial firms' total equity; $P R O P \_L H T=$ proportion of firms a bank holds equity positions in for a duration of either 3, 4 or 5 years; $P R O P \_C O N T R=$ proportion of firms a bank holds equity investment in where it is the majority shareholder. 


\section{Table A2. Levels of shareholder protection index}

\begin{tabular}{|l|c|}
\hline Country & Shareholder protection index \\
\hline Austria & 2,5 \\
Belgium & 3 \\
Denmark & 4 \\
Finland & 3,5 \\
France & 3,5 \\
Germany & 3,5 \\
Greece & 2 \\
Ireland & 5 \\
Italy & 2 \\
Luxembourg & 2 \\
Netherlands & 2,5 \\
Norway & 3,5 \\
Portugal & 2,5 \\
Spain & 5 \\
Sweden & 3,5 \\
Switzerland & 3 \\
U.K. & 5 \\
\hline
\end{tabular}

Shareholder protection index $=$ revised anti-director rights index (Djankov et al. 2008) 
Table A3. Overall exposure to equity investment activities and risk for commercial banks, crosssectional over the period 2004-2008

\begin{tabular}{|c|c|c|c|c|}
\hline & \multicolumn{2}{|c|}{$\begin{array}{l}\text { Activity risk } \\
\end{array}$} & \multicolumn{2}{|c|}{ Insolvency risk } \\
\hline & SD_ROA & SD_ROE & LOG_Z & LOG_ZP \\
\hline EXPOS1 & $\begin{array}{l}0.120^{* *} \\
(0.023)\end{array}$ & $\begin{array}{l}1.923^{* * *} \\
(0.008)\end{array}$ & $\begin{array}{c}-0.540^{* * * *} \\
(0.002)\end{array}$ & $\begin{array}{c}-0.489^{* * *} \\
(0.004)\end{array}$ \\
\hline NL_TA & $\begin{array}{l}0.0112 \\
(0.707)\end{array}$ & $\begin{array}{c}0.312 \\
(0.410)\end{array}$ & $\begin{array}{c}-0.0948 \\
(0.260)\end{array}$ & $\begin{array}{c}-0.0743 \\
(0.360)\end{array}$ \\
\hline NONINT & $\begin{array}{c}0.00230 \\
(0.244)\end{array}$ & $\begin{array}{l}0.0459^{*} \\
(0.068)\end{array}$ & $\begin{array}{c}-0.0164^{* * * *} \\
(0.004)\end{array}$ & $\begin{array}{c}-0.0165^{* * *} \\
(0.003)\end{array}$ \\
\hline EQ_TA & $\begin{array}{c}0.00195 \\
(0.830)\end{array}$ & $\begin{array}{c}-0.319^{* *} \\
(0.018)\end{array}$ & $\begin{array}{c}0.0700^{* *} \\
(0.041)\end{array}$ & $\begin{array}{c}0.0693^{* *} \\
(0.035)\end{array}$ \\
\hline LOG_TA & $\begin{array}{c}-0.0660^{* *} \\
(0.032)\end{array}$ & $\begin{array}{l}-0.585 \\
(0.200)\end{array}$ & $\begin{array}{c}0.146 \\
(0.194)\end{array}$ & $\begin{array}{c}0.122 \\
(0.263)\end{array}$ \\
\hline GR_TA & $\begin{array}{c}0.00365 \\
(0.304)\end{array}$ & $\begin{array}{l}0.0189 \\
(0.594)\end{array}$ & $\begin{array}{l}-0.0110 \\
(0.126)\end{array}$ & $\begin{array}{l}-0.0115 \\
(0.103)\end{array}$ \\
\hline ROA & $\begin{array}{l}0.121^{* *} \\
(0.032)\end{array}$ & - & - & - \\
\hline ROE & $\begin{array}{l}- \\
-\end{array}$ & $\begin{array}{l}0.0472 \\
(0.487)\end{array}$ & - & - \\
\hline SUP_REG & $\begin{array}{l}-0.0209 \\
(0.273)\end{array}$ & $\begin{array}{l}-0.317 \\
(0.116)\end{array}$ & $\begin{array}{l}0.212^{* * * *} \\
(0.000)\end{array}$ & $\begin{array}{c}0.203^{* * *} \\
(0.000)\end{array}$ \\
\hline ACT_REST & $\begin{array}{l}-0.0253 \\
(0.144)\end{array}$ & $\begin{array}{c}-0.565^{* * *} \\
(0.006)\end{array}$ & $\begin{array}{l}0.129^{* * *} \\
(0.007)\end{array}$ & $\begin{array}{l}0.112^{* *} \\
(0.017)\end{array}$ \\
\hline Constant & $\begin{array}{l}0.824^{* *} \\
(0.018)\end{array}$ & $\begin{array}{l}13.73^{* * *} \\
(0.004)\end{array}$ & $\begin{array}{c}1.087 \\
(0.359)\end{array}$ & $\begin{array}{c}1.396 \\
(0.221)\end{array}$ \\
\hline Final estimation method & IV-GMM & IV-GMM & IV-GMM & IV-GMM \\
\hline $\begin{array}{l}\text { IV tests (P-values): } \\
\text { Endogeneity: EXPOS1 } \\
\text { Underidentification } \\
\text { Overidentifying restrictions }\end{array}$ & $\begin{array}{l}0.004 \\
0.023 \\
0.908\end{array}$ & $\begin{array}{l}0.000 \\
0.013 \\
0.626\end{array}$ & $\begin{array}{l}0.000 \\
0.016 \\
0.704\end{array}$ & $\begin{array}{l}0.000 \\
0.016 \\
0.851\end{array}$ \\
\hline Observations & & & & \\
\hline
\end{tabular}

P-values of coefficient estimates in parentheses, with $p<0.1^{*}, p<0.05^{* *}, p<0.01^{* * *}$.

Variable definitions: as defined in Table 5.

IV tests: endogeneity tested with C test (H0: exogeneity); underidentification tested using the Kleibergen-Paap rk LM statistic (H0: irrelevant instruments); overidentifying restrictions tested using Hansen test (H0: valid instruments). 